\title{
Water for all: towards an integrated approach to wetland conservation and flood risk reduction in a lowland catchment in Scotland.
}

\author{
Andrew Vinten ${ }^{1}$, Laure Kuhfuss ${ }^{1,4}$, Orla Shortall ${ }^{1}$, Jenni Stockan ${ }^{1}$, Ade Ibiyemi ${ }^{1}$, Ina Pohle ${ }^{1}$, \\ Stephen Addy ${ }^{1}$, Marjorie Gabriel ${ }^{2}$, lain Gunn ${ }^{3}$ and Linda May ${ }^{3}$. \\ ${ }^{1}$ SEGS Group, the James Hutton Institute, ${ }^{2}$ ENGEES, France, ${ }^{3}$ Centre for Ecology and Hydrology, \\ ${ }^{4}$ SGSD, University of St Andrews
}

\section{Abstract and keywords}

Strategies for sustainable water resources management require integration of hydrological, ecological and socioeconomic concerns. The "Water for all" project has sought to develop a multi-disciplinary science case for innovative management of water levels and flows in a lowland catchment in Scotland. Water demands of arable agriculture, protection from flood risk and conservation needs of lowland mesotrophic wetlands needed to be considered. Water management strategy focused on the outlet zone of Balgavies lake in Eastern Scotland, where the Lunan Water discharges into a partially confined common channel (lade) Water releases to a mill, to the downstream river, and to floodplain wetlands (Chapel Mires) are partially controlled by an existing weir. Based on observations of management of this weir, we postulated that upgrading hydraulic management in this zone could reduce upstream flood risk, help protect mesotrophic wetlands and facilitate downstream water supply at low flows. We considered potential for: (a) installing remotely operated tilting weir, for improved management of release and routing offlows from the common lade; (b) dredging of the common lade in combination or instead of the tilting weir. Rapid ecological assessment and mixing analysis of the Lunan Water with waters in Chapel Mires showed a gradient of trophic status across the wetlands linked to impact of river-borne nutrients. Stage-discharge relationships, derived from steady-state approximations of the in-channel hydraulics, showed that the proposed tilting weir had potential to divert seasonal nutrient rich water from the upstream Lake away from Chapel Mires. Significant impact of the proposed weir on upstream flood risk was not demonstrated, but carrying out dredging of the channel reduced the current observed probability of upstream flooding. The proposed weir could help to maintain these dredging benefits. Survey and interviews with catchment stakeholders and residents showed constructive interest in the scheme, with half of the respondents willing to pay to support its implementation. The survey also revealed concerns about the proposed project, especially its long-term governance. The lessons learned have wider relevance to development of an integrated approach to water ecosystem services provision, especially where benefits are uncertain and thinly spread across a range of users.

Keywords: nutrient enrichment; catchment management; hydraulic modelling; socio-economic assessment; ecohydrology

\section{Introduction}

Integrated catchment management needs prior characterisation of aquatic ecosystem function (e.g. Covino, 2017; Bino et al., 2015) and associated services and values (Turner et al., 2000; Gilvear et al., 2013; Lamers et al., 2015). Understanding historic change is needed to provide baselines (Ncube et al., 2018), while uncertainty in governance as well as hydrology should be recognised (Rouillard et al., 2013; Höllermann and Evers, 2017). Demands for water ecosystem services need to be identified and balanced (e.g. Guan et al., 2016; Xia et al., 2016; Kingsford, 2000; Acreman et al., 2009). An important research question is how to integrate multi-disciplinary assessment of water management options (e.g. Brouwer and van Ek, 2004). Integrated assessment is not based on fixed disciplinary boundaries, but on boundaries defined by specific catchment issues (Rotmans, 1996, quoted in Brouwer et al., 2004). To explore integrated assessment, specific case studies are valuable. This paper considers the potential for 
use of adjustable hydraulic controls for managing flood risk, wetland hydro-ecology and low flows in the Lunan Water, a lowland agricultural catchment in Eastern Scotland. Analysis focuses on a 'pinch-point' in the hydrology at the outlet zone of Balgavies lake (Figure 1). Stakeholders in the upper catchment (above the outlet of Balgavies lake) are affected by flooding leading to pressure for improved flood controls in the form of channel dredging or modified hydraulic management in this zone (Figure 2). The lake and a downstream tributary, the Balgavies Burn, discharge into a partially confined common lade feeding a restored water mill controlled by an existing weir which partitions water between a mill lade, floodplain wetlands and return flow to the Lunan Water. Nutrient and sediment in discharge from the lake display strong seasonal variation. Part of this discharge spills into a floodplain wetland (Chapel Mires) which is botanically rich but vulnerable to eutrophication, as are many lateral floodplain wetlands (Acreman et al., 2007; Kearney, Riter and Turner, 2011; Turner, Bodker and Schulz, 2018). Downstream, the river is at risk of low flows which can restrict availability of water for irrigation in summer and cause damage to river ecology (Vinten, 2017).

There is ongoing debate as to how to achieve multiple objectives in water management without incurring disproportionate costs (Bizzi et al., 2012; Turner et al., 2000; Vinten et al., 2012). Passive approaches, such as Natur al Flood Management (e.g. Wilkinson et al., 2014; O'Connell, Ewen, O'Donnell and Quinn, 2007; Fliervoet, van den Born, and Meijerink, 2017;) are gaining acceptance. However, where full restoration of natural processes is hard to achieve, such as in intensive lowland agricultural catchments (Meert et al., 2016), small, adjustable hydraulic structures, e.g. tilting weirs (Aquatic Control Engineering, 2004) may be beneficial. These can provide water level, flow and diversion control, at relatively low cost, giving potential for adaptive water management. For example, hydraulic controls are a crucial aspect of flood defence (http://www.ecsengineeringservices.com/new-tilting-weirhelps-somerset-flood-defences/), wintering geese conservation (Guan et al., 2016), and ecological management of shallow lakes (Coops and Hosper, 2002). The economic benefits of such management may be quantifiable (e .g. Bizzi et al., 2012), facilitating introduction of Payments for Ecosystem Services (PES) approaches to delivery of integrated water management to offset costs (Muradian, Corbera, Pascual, Kosoy and May, 2010; Martin-Ortega, Ojea and Roux, 2013). In developing an integrated approach to water management assessment in the Lunan Water catchment, we aimed to develop a case for such a scheme.

First steps in this integrated assessment comprised four main components:

1. Hydrological analysis focused on deriving steady-state stage-discharge relationships for in-channelflow, in connection to standing waters, as a function of: (a) existing or proposed management of hydraulic structures and (b) dredging. This used water level monitoring and survey data and a hydraulic modelling tool (HECRAS, 2016). It allowed estimation of upstream water levels and partitioning of flows.

2. Ecological assessment of Chapel Mires wetland using the UK National Vegetation Classification scheme (Rodwell, 1995).

3. Mixing behaviour of water from the river with other sources contributing to the wetlands, using End Member Mixing Analysis (Hooper, 2016).

4. Governance and stakeholder analysis. This focused on willingness to pay (WTP) for a tilting weir option, and interviews discussing the uncertainties and governance gaps that might impede implementation.

5. Assessment of risk to ecological status of the river and abstraction limitations caused by low flows. A weir at the Lake outlet could facilitate retention of water in early summer in the Lakes, providing water for abstraction and maintain low flows. This element was considered in detail in Vinten et al. (2017).

\section{Materials and Methods}

\section{Study region}

The Lunan Water (Figure 1) drains a mixed arable catchment of $134 \mathrm{~km}^{2}$ in Angus, Eastern Scotland, UK (Dunn et al., 2014). Mean annual precipitation is $755 \mathrm{~mm}$ and mean annual temperature is $8.1^{\circ} \mathrm{C}$ (1981-2010). Maximum 
elevation is $250 \mathrm{~m}$ a.s.I. (above sea level) at Turin Hill descending to a broad valley, bounded by steeply sloping fields. Much of the catchment area is underlain by groundwater bodies in Devonian Sandstone. The superficial glacial sands and gravels which border the river channel network are highly productive aquifers. Alluvium underlies the two lakes in the upper catchment, Rescobie and Balgavies lakes (Ó Dochartaigh, Macdonald, Fitzsimons and Ward, 2015), with their surrounding wetlands. The Lunan Water shows a high inter-annual discharge variability for both floods and dry periods. Mean flow (1981-2016) was $1.73 \mathrm{~m}^{3} / \mathrm{s}, \mathrm{Q}_{5}=6.04 \mathrm{~m}^{3} / \mathrm{s}$ and $\mathrm{Q}_{95}=0.20 \mathrm{~m}^{3} / \mathrm{s}$ (NERC, 2018). The values of $\mathrm{Q}_{99}$, $\mathrm{Q}_{95}, \mathrm{Q}_{5}$, and $\mathrm{Q}_{1}$ (discharge exceeded on $99 \%, 95 \%, 5 \%$ and $1 \%$ of the days, respectively) for the part of the catchment upstream of Balgavies lake outlet ( $a r e a, A=23.7 \mathrm{~km}^{2}$ ) were estimated by scaling to be $0.03,0.04,1.15$ and $2.34 \mathrm{~m}^{3} / \mathrm{s}$ respectively. Both lakes fail the Water Framework Directive (WFD) standard for annual mean total phosphorus $(\mathrm{P})$ and chlorophyll a, but have improved in recent years due to improved diffuse pollution management, reduced livestock numbers and sewage treatment. They show significant peaks in total and soluble $P$ concentrations in late summer/autumn due to release from anaerobic sediments as reflected by seasonally high loads of $P$ from Balgavies lake into the Lunan Water (Grieve and Gilvear, 1994). For example, Balgavies lake outflow had a mean soluble P concentration of $89 \pm 44 \mu \mathrm{g} / \mathrm{L}$ in October compared with $11 \pm 9 \mu \mathrm{g} / \mathrm{L}$ in March during 2011-2018. Nitrogen (N) loads from the lake are mitigated due to denitrification, but Balgavies Burn, which runs into the Lunan Water just downstream of the Lake, has high N loads in winter. For example, Balgavies Burn had a mean nitrate-N concentration of $8.0 \pm 2.5 \mathrm{mg} / \mathrm{L}$ in December, but only $5.6 \pm 1.3 \mathrm{mg} / \mathrm{L}$ in August during 2011-2018. High sediment loads occur in late autumn because of erosion from arable farmland, especially after potato harvest (Vinten et al., 2013).

The Lunan Water has several morphological alterations associated with functional and derelict water mills on the river. (EnviroCentre, 2014). These include the hydraulic structures downstream of Balgavies lake (Figure 2), designed to bring water to the water mill at Milldens (Easting: 354788 Northing: 750442, UTM co-ordinate system, grid zone $30 \mathrm{~V})$. Figure 2 also shows possible sitings for a proposed tilting weir to actively manage flows. A detailed description of this system is provided in Supporting Information 1 and 2.

Chapel Mires, the floodplain wetlands downstream of Balgavies lake (Figure 2) shows a complex mosaic of open water, willow scrub and sedge-dominated fen vegetation. These include, using the UK National Vegetation Classification (Rodwell, 1995), classes M9 (Carex rostrata-Calliergonmire), M27 (Filipendula ulmaria-Angelica sy/vetrismire), S28 (Phalarisswamp), S9 (Carex rostrataswamp) and S27a (Carex rostrata-Equisetum fluviatile subcommunity) occupying the lower lying areas. Several of the wetland species present such as Bogbean (Menyanthes trifoliate L.), Bladderwort (Utricularia australis aggR.Br.), the nationally scarce Cowbane (Cicuta virosaL.) and Tufted Loosestrif e (Lysimachia thyrsiflora L.) only occur in shallow water and vulnerable to changes in water quality and levels (Holaday et al., 2015; Jing et al., 2017).

\section{Hydrological assessment}

\section{Modelling of lake levels and outflow}

The daily change in water level in Balgavies lake depends on the daily inflow into the lake, the previous day's water level and the stage-discharge relationship describing outflow from the lake as a function of water level and position of weir gates in the lade downstream. Lake inflow was obtained by scaling up the inflow from Balgavies Burn to the lake catchment area:

$H_{L}{ }^{(t)}=H_{L}{ }^{(t-1)}+\left(\left(Q_{B} A_{L C} / A_{B C}\right)-Q_{0}\right) / A_{L}$

$H_{L}{ }^{(t)}, H_{L}{ }^{(t-1)}=$ Water level in the lake on dayt, t-1 ( $m$ above sea level)

$Q_{B}=$ daily discharge of Balgavies Burn ( $\left.m^{3} / d\right)$

$A_{L C}=$ total catchment area of Balgavies lake outlet $\left(23.7 \times 10^{6} \mathrm{~m}^{2}\right)$

$A_{B C}=$ catchment area of Balgavies Burn $\left(4.40 \times 10^{6} \mathrm{~m}^{2}\right)$ 
$A_{L}=$ Area of open water and wetlands which contributes to water level change observations on Balgavies lake (taken as $1.86 \times 10^{6} \mathrm{~m}^{2}$ ).

$Q_{0}=$ discharge from Balgavies lake, derived from a stage-discharge curve, $Q_{0}=f\left(H_{L}\right)\left(m^{3} / d\right)$.

\section{Measurement of water levels and flows}

Maximum, minimum and current water levels for Balgavies lake were measured fortnightly using water level maximum/minimum recorders (Bragg et al., 1994) during 2003-2014 by Scottish Wildlife Trust (A. Houghton, pers. comm., 2014). High resolution water level recorders (Frog Systems and Van Walt) were installed from April 2014 at three points in the lake system: Balgavies lake, Rescobie Lake and the common lade upstream of Milldens weir (Figures 1 and 2). Water levels were recorded at 15 minute intervals and referenced to British National Grid Datum (J. Compton, pers.comm. 2010). Precipitation at Mains of Balgavies and discharge of the Balgavies Burn have been monitored since 2006 (Dunn et al., 2014).

To assess the response of the Chapel Mires wetlands to changing lake water levels, the position and elevation of the water margin at several key points in Chapel Mires were measured in May-July 2015 and again in May-June 2017 using a Leica Geosystems 1200 differential global positioning system ( $d G P S$; elevation accuracy: $\pm 3 \mathrm{~cm}$ ). Water level at the northern end of the culvert located between the Ponds and southern most wetland sections of Chapel Mires (easting 353952 northing 750468) was recorded during 2017-2018 using a diver(MMG) and associated baro-diver air reference.

Discharge measurements on the common lade and Chapel Mires spillway were made with the return gate open and closed, using a propeller flowmeter (Valeport model 001) on 26-27/7/2016 and 27-28/9/2016, and an acoustic Doppler based Valeport flowmeter model 801 on 11/7/2016 (see Vinten et al., 2017 for more details). Further measurements were made on 30-31/10/2017 to measure flows at Chapel Mires spillway and a cross section just downstream of this spillway. Note that it was not possible to obtain data at higher winter water levels because access to Chapel Mires in winter was restricted due to recreational shooting activity Longitudinal water level measurement in summer was also restricted by the impact of leaves on signal reception for the dGPS.

\section{Channel cross sections}

Nine cross sections of the common lade were surveyed on 31/10/2017 during low flow conditions to provide topographical information for hydraulic modelling. An Impulse 200 laser range finder (vertical accuracy: $\pm 3 \mathrm{~cm}$ ) and the dGPS were used to survey channel cross sections. On average, points were taken every $1 \mathrm{~m}$ along each cross section. At each point, the dominant channel substrate or terrestrial vegetation/material type was classified to inform calibration for Manning's n roughness values necessary for the hydraulic model and water level points were measured to allow model calibration. Some cross-section data were collected in May/June 2015 using the dGPS. Although it was somewhat older information (1977-1998), we used bed level data from a historical survey carried out by a local farmer (J. Compton, pers.comm., 2010). Balgavies lake (area 59 ha, average depth $3 \mathrm{~m}$ ) has cross sectional dimensions defined by a bathymetric survey of the lake (National Library of Scotland, 2006). Supporting information 2 summarises the cross-sectional data used for model simulations.

\section{Hydraulic modelling and hydrological response to weir managementand dredging}

For the initial hydraulic analysis described in this paper, we assumed flow from Balgavies lake along the Common Lade occurred in a well-defined, confined channel with default Manning coefficient of 0.03 . The Lunan Water tributary, Balgavies Burn, also provides an inflow. A longitudinal cross section of this simplified channel is shown in Supporting information 3. A key feature of this channel is a $0.9 \mathrm{~m}$ wide in-line weir gate (bed level $59.04 \mathrm{~m}$, distance from Balgavies lake $451 \mathrm{~m}$ ) directing water into Milldens Lade at Milldens weir - see supporting information 2). This has been modelled as a $1 \mathrm{~m}$ long, $0.9 \mathrm{~m}$ wide constriction to flow which is always open. A further key feature is a culverted bridge (bed level $58.98 \mathrm{~m}$ a.s.l., chainage $370 \mathrm{~m}$ ) over the channel, which has been represented by a $4 \mathrm{~m}$ long, $3.5 \mathrm{~m}$ wide constriction. 
Cross section data were used to define the bed of this channel, but for this initial appraisal, banksides were assumed to be high enough not to allow lateral flow, except through three defined lateral structures modelled as rectangular weirs:

- the existing Chapel Mires spillway (CMS - distance from Balgavies lake outlet 220m, width of rectangular section $2.7 \mathrm{~m}$, bed level $58.9 \mathrm{~m}$ );

- the proposed tilting weir located just upstream of the confluence of Balgavies Burn (TiW- distance from Balgavies lake outlet $394 \mathrm{~m}$ ), with width of rectangular section $1.8 \mathrm{~m}$ and minimum level $58.6 \mathrm{~m}$. Note that without dredging, this is the furthest upstream that a minimum level for the weir as low as $58.6 \mathrm{~m}$ can be achieved;

- The existing return gate to the Lunan Water at Milldens weir (RET - chainage from Balgavies lake outlet $453 \mathrm{~m}$, width of rectangular section $0.9 \mathrm{~m}$, bed level $59.04 \mathrm{~m}$ ).

We inputted cross section and hydraulic structure data into a hydraulic model (HECRAS 5.0.1, 2016). The longitudinal profile shown in Supporting Information 3 also gives an example steady inflow of $5 \mathrm{~m}^{3} / \mathrm{s}$ from the upstream Lunan Water and $0.1 \mathrm{~m}^{3} / \mathrm{s}$ from the Balgavies Burn.

Steady inflow from upstream of the lake and from Balgavies Burn were varied to generate a series of steady-state water levels in the Balgavies lakeBalgavies lake and in the channel downstream, and hence generate the required stage-discharge curves, as a function of (a) hydraulic control settings of the existing weir on the common lade at Milldens, (b) inflow to the common Lade from the Balgavies Burn tributary $\left(Q_{B}\right)$, (c) the proposed new tilting weir just upstream of the confluence of Balgavies Burn, (d) dredging the Common lade channel between the outlet of Balgavies lakeBalgavies lake and Milldens weir by $50 \mathrm{~cm}$ (e) dredging combined with siting the tilting weir further upstream at the site of an old, blocked spill way at chainage $279 \mathrm{~m}$, with an option to close the existing Chapel Mires spillway.

The model was run for a series of steady-state flows in the following combinations: $Q_{0}=0.1,0.5,1,2,4,5,6$ or 8 $\mathrm{m}^{3} / \mathrm{s} ; \mathrm{Q}_{\mathrm{B}}=0.1,0.3,0.7$ or $1 \mathrm{~m}^{3} / \mathrm{s}$; only Chapel Mires spillway open; Chapel Mires spill way and return gate open; Chapel Mires spillway, tilting weir and return gate open; common lade channel downstream of Chapel Mires spill way was either undredged or dredged by $0.5 \mathrm{~m}$. The results from these simulations were used to generate lookup tables of Balgavies lake stage $\left(H_{L}\right)$ vs discharge $\left(Q_{0}\right)$ and the modelled discharges could then be used to simulate water levels in Balgavies lake using the hydrological model ling. Sensitivity analysis considered the impact of modifying the Manning coefficient for the channel and model efficiency was evaluated by the Nash-Sutcliffe coefficient (Nash and Sutcliffe, 1970).

Simulations of water levels were performed over the period from March 2014 to November 2017 for 6 different combinations of hydraulic controls:

1. Tilting weir closed, Milldens return gate closed

2. Tilting weir closed, Milldens return gate open

3. Tilting weir open, Milldens return gate open

4. Tilting weir closed, Milldens return gate open, channel dredged by $0.5 \mathrm{~m}$

5. Tilting weir open, Milldens return gate open, channel dredged by $0.5 \mathrm{~m}$

6. As 5 , but tilting weir shifted to old, currently blocked spillway at chainage from lake outlet $=279 \mathrm{~m}$

In all these cases we assumed Chapel Mires spillway was open.

\section{Ecologicalassessment}

\section{Vegetation survey of Chapel Mires}

To assess the present condition of the Chapel Mires, a rapid appraisal of the UK National Vegetation Classification (NVC) classes over the site, supported by survey with the dGPS and aerial photographs, was carried out over 2 days 
in June 2017. The information obtained was used to construct a map of the area showing NVC classes for the nonopen water areas. Two vegetation quadrats $(3 \mathrm{~m} \times 1.5 \mathrm{~m})$ were installed in 2015 and species identification was done in May and July of that year, and again in June 2017. These were Q1 (NVC class 27a) and Q2 (NVC class 27a). A pre existing quadrat site, quadrat Q3, was sampled during June 2017 (NVC class W3/S28). We used community-weighted Ellenberg values (Ellenberg, Düll, Wirth, Werner, and Paulißen 1991) to compare Ellenberg $\mathrm{N}$ and moisture (water levels) in each of the quadrats.

A survey of the submerged and emergent aquatic vegetation in open water ponds in the Chapel Mires wetla nd was carried out in September 2017. Ponds 1 and 2 were surveyed from an inflatable boat by means of visual assessment supplemented by regular sampling of the submerged macrophyte communities by use of a double -headed rake. The macrophytes in the Inlet Pond (the northernmost pond) were sampled from the bank using throws of the double headed rake.

\section{End member mixing analysis for Chapel Mires}

Details of the chemical analysis methods for these and routine monitoring samples of the outlet to Balgavies lake and rainfall are given in Dunn et al. (2014). Water samples were collected periodically from the two quadrat sites $Q_{1}$ and $Q_{2}$ during 2015-2018. In addition, samples were collected from a third site, $Q_{x}$ and during the survey of wetted margin in 2015 and 2017 (details see Supporting Information 4 details). To estimate the contribution of the water exiting Balgavies lake to water quality of Chapel Mires we carried out principal component analysis and end member mixing analysis (EMMA) using the methodology of Christopherson and Hooper (1992) and Hooper (2016). EMMA evaluates the ability of potential water source components, obtained from independent data, to reproduce mixed water chemistry, using a constrained least squares solution. We chose $\mathrm{Ca}, \mathrm{Mg}, \mathrm{Na}, \mathrm{Si}, \mathrm{F}$ and $\mathrm{K}$ for mixing analysis as these showed differences across potential end members, are likely to behave conservatively under changing redox, and do not duplicate. The potential end members that we considered initially were outflow from the Balgavies lake, Balgavies Burn, rainfall, presumed groundwater-fed woodland ponds located in topographic depressions in woodland adjacent to the south east of Chapel Mires, and a roadside gully pot to the south of the area (Chapel Mires area is bounded to the south and west by roads generating contaminated runoff containing high $\mathrm{NaCl}$ ). The excelbased EMMA package we used allowed for 3 end members, so we selected the presumably most meaningful end, i.e rainfall (sampled on 28/02/12), Balgavies Loch outflow (sampled 1/2/17) and the Western end of Chapel Mires wetland (assumed to comprise field drainage and road runoff, 30/10/2017).

\section{Socioeconomic assessment}

\section{Catchment group}

A Lunan Water Catchment Management Group was set up in April 2016 to provide steering and oversight to the

"Water for All" project, and to highlight any other catchment issues in need of consideration. This was chaired by the local authority (Angus Council) and members included the main regulatory bodies (Scottish Environment Protection Agency, Scottish Natural Heritage) and local interest groups (Esk Rivers and Fisheries Trust, Balgavies lake Committee, Scottish Wildlife Trust, National Farmers Union Scotland) and members of the research team.

\section{Scoping and pre-surveyinterviews}

Stakeholder survey and engagement in the catchment followed previous interviews, which were carried out in 2014 (Shortall, Rear, Vinten, Novo and Kuhfuss, 2017) with stakeholders including farmers, land owners and representatives from governmental and non-governmental organisations with involvement in the management of the Lunan Water. These interviews explored views on water issues in the catchment, causes and potential solutions and the potential to establish a scheme to pay for water benefits in the catchment. Flooding, loss of topsoil, water shortages, threats to catchment ecology and shortage of hydrological data were seen as key issues to discuss. Presurvey interviews, to confirm the scope of a subsequent will ingness to pay (WTP) survey and the suitability of survey information, werealso performed in February/March 2017. 


\section{Willingness to pay survey}

To quantitatively measure support from local stakeholders for the project, and assess its potential long-term financial viability, we used a WTP approach through contingent valuation (Carson, 2000). A postal and online survey useda mix of closed and open-ended questions. After a series of questions relative to their familiarity and perception of the Lunan Water, a brief description of the scheme and its potential effects on flood risks, low flows and wetland biodiversity was presented. Respondents were then asked to state the maximum WTP over 10 years on a choice card presenting 6 options ( $f 0, £ 2, £ 5, £ 7, £ 10, £ 15, £ 25, £ 40$ per year), in a different random order for each respondent. The questionnaire ended with some socio-demographic questions.

To investigate the preferred institutional arrangements for the long-term governance of the scheme, respondents were asked their WTP to support financially the implementation of the same project for water levels management under 3 different governance scenarios:

1. Management of water levels by the local government, Angus council, with funding levied through a council tax increase for 10 years;

2. Management of water levels by a business run by local stakeholders who would buy shares once for 10 years;

3. A charity would oversee the water levels, while funding would come from donations. In this scenario, respondents were asked to state their WTP in the form of an annual membership to the charity for the next 10 years.

The postal survey was randomly sent to 60 farmers and 200 residents from the Lunan Water catchment. 5,000 leaflets were distributed in mailboxes and advertised in the catchment area to advertise the online version of the survey. 12 farmers and 61 residents responded, with 39 from the postal survey and 34 from the internet survey. 62 of the 73 respondents live in the catchment; the 11 other lived in Angus. Confidence interval was estimated by bootstrapping using the Bias Corrected method and 1000 replications.

\section{Post-surveyinterviews}

To further explore stakeholder views about water management and the proposed tilting weir scheme, 17 interviews were carried out with 19 stakeholders in the Lunan Water catchment. Eight people in stakeholder organisations in the catchment, three farmers and eight residents were interviewed. Members of stakeholder organisations were recruited through their involved in the Lunan Water catchment management group. Farmers and residents were recruited through participating in the survey. The interviews dealt with people's views on water issues in the Lunan Water catchment in general, different ways of managing these, and their views on the desirability and feasibility of the proposed scheme. Interviews lasted around 1 hour and were recorded and transcribed.

\section{Results and Discussion}

\section{Hydrological assessment}

\section{Water levels in Rescobie and Balgavies lakes, Common Lade and Chapel Mires}

The fortnightly water levels in Balgavies lake for 2003-2018 showed a significant upward linear trend of $3.6 \mathrm{~mm} /$ year ( $p$-value $=0.027)$; an upward trend of $6.4 \mathrm{~mm} /$ year ( $p$-value $=0.01$ ) was detected for annual minima but not for annual maxima. The 15 minute interval water levels for 2014-2018 for Rescobie and Balgavies lake and for Milldens weir are shown in Figure 3. Annual water level fluctuations showed an amplitude of up to $1 \mathrm{~m}$ at Rescobie Lake, up to $1.2 \mathrm{~m}$ at Balgavies lake and up to $0.75 \mathrm{~m}$ in the common lade upstream of Milldens weir. The range was much larger in 2015-2016 than in 2014-2015 because of a major flood event (Storm Frank, 28-29/12/2015). This event was an important driver to local government interest in flood risk reduction. It inundated roads (when Rescobie water level $>60.0 \mathrm{~m}$ ) and property upstream of Rescobie Lake, fields downstream of Balgavies lake in the Milldens area, and further downstream. 
At low flow, in Rescobie Lake levels were about $0.2 \mathrm{~m}$ higher than in Balgavies lake, but this difference was smaller at high flows. There was little lag $(<1 \mathrm{~d})$ between the response of Rescobie and Balgavies lakes, or between Milldens weir and Balgavies lake, but Milldens weir generally responded before Balgavies lake, due to the input from Balgavies Burn.

The position of the return gate delivering water from the common lade to the Lunan Water at Milldens was critical to the difference in water levels between the common lade upstream of Milldens weir and Balgavies lake. With the return gate closed, the water levels between the Balgavies outlet and upstream of Milldens weir/downstream of Balgavies Burn did not differ $( \pm 0.04 \mathrm{~m})$, highlighting the potential for flow reversal if the return gate were closed. Based on empirical observations of impact of gate closure in summer 2016, we estimated that the outflow from Balgavies lake decreased as a result of gate closure by about $12 \mathrm{~L} / \mathrm{s}$ compared to that for the gate open condition, for every $1 \mathrm{~cm}$ of water in the lake above 59.37m (details see Vinten et al., 2017).

Water levels observed at the culvert between the ponds and the small wetland in the southern part of Chapel Mires from June 2017 to March 2018 show that, in summer and early autumn, changes in water level in Chapel Mires occurred without change in lake levels and showed little hysteresis, suggesting groundwater control and/or input from the higher ground to the south of Chapel Mires (supporting information 5). A widening hysteresis loop during September to November 2017 implies filling of ponds 1 and 2. This acted a barrier from the north, slowing drainage of surface runoff from the south through the small wetland. In the December 2017-January 2018 event, a totally different response occurs, with long lasting hysteresis and an anticlockwise loop. This probably reflects the point at which direct filling of the small wetland from the north occurred, corresponding to a lake water level of around $59.7 \mathrm{~m}$. This lake level could serve as a useful guide for when control of water entering Chapel Mires from the common lade could prove directly beneficial to reducing nutrient loads, to the southernmost (best conserved) part of Chapel Mires al though lower water levels are relevant to nutrient loading from the river to the two ponds. Our inference from these observations is that Chapel Mires received water from the river, but that the southern part of the wetland was quite well protected from these inputs, except at high lake levels $(>59.7 \mathrm{~m})$ and river flows. The risk of Balgavies Lake water level exceeding $59.7 \mathrm{~m}$ for $2003-2010$ was $6.4 \%(3.4 \%, 9.8 \%)$ and $10.8 \%(5.8 \%, 16.6 \%)$ for 2011-2018.

\section{Model simulations of stage-discharge vs gate positions and dredging}

A suite of stage-discharge relationships between the water level in Balgavies lake and the discharge from the lake, for steady state flow conditions, using HECRAS 5.0.1 model assuming a Manning coefficient of 0.03 throughout, was obtained (supporting information 6). This was done for different conditions of inflow from Balgavies Burn and operation of gates providing lateral offtake, namely the return gate at Milldens weir, and the proposed tilting weir just upstream of the Balgavies Burn tributary. High Balgavies Burn inflow restricted discharge from Balgavies lake, especially at low lake outflows. The impact of the position of the Milldens return gate on the flow out of the lake was most marked at very high and at low water levels and nearly non-existent at moderate to high levels, except for the largest Balgavies Burn tributary inflows. Below Balgavies lake outflow of $4 \mathrm{~m}^{3} / \mathrm{s}$, there was very little impact of adding a lateral tilting weir on water levels in the lake, but the impact increased at very high outflows. This smaller than expected impact was partly because of the accumulation of sediment, for example at chainage 237-279 m and at the cattle drinking point just upstream of the culverted bridge at chainage $=374 \mathrm{~m}$ (supporting Information 2). The impact on stage-discharge relationships of $0.50 \mathrm{~m}$ of dredging of the Common Lade (for location of dredging see dotted line in supporting information 3) on lake water levels was much larger than the impact of the tilting weir operating in the undredged channel, except at very high outflows. For example at $\mathrm{H}_{\mathrm{L}}=59.6 \mathrm{~m}$, lake outflow was doubled from 1 to $2 \mathrm{~m}^{3} / \mathrm{s}$ by dredging. Dredging also made the tilting weir more effective, furtherincreasing the flow from the lake when $\mathrm{H}_{\mathrm{L}}>59.6 \mathrm{~m}$. We also considered the effect of moving the tilting weir site upstream of the bridge (feasible once the channel is dredged). We chose the site of an old, blocked spi llway (Figure 2) near the bend in the common lade, as we hypothesise that the transfer of the spillway to the present site may have promoted accumulation of sediment in this portion of the common lade. This modification gave a further increment in the impact of the tilting weir at high water levels $\left(\mathrm{H}_{\mathrm{L}}>60 \mathrm{~m}\right)$, even if the Chapel Mires spillway was closed off. 


\section{Hydrological modelling of Balgavies lake and Milldens weir waterlevels}

The suite of stage-discharge curves were used to generate "lookup tables" to allow the hydrological model to operate dynamically across a range of values of $H_{L}, Q_{B}$ and weir settings (Figure 3 , based on equation 1 ). The simulation period (March 2014-November 2017) includes two winters where water levels in Balgavies lake rose to values $>59.8 \mathrm{~m}$, a critical level for flooding, for $7 \mathrm{~d}$ (2014-2015) and 31d (2015-2016) respectively. The water levels during summer fell to around $59.4 \mathrm{~m}$. Modelling of the Balgavies lake levels under current weir and channel conditions agreed reasonably well with the observed data (Nash-Sutcliffe coefficient $=0.75$, mean difference between observed and predicted level $=6.6 \mathrm{~cm}$, relative efficiency $=0.83$ ), but there were periods when significant discrepancies occur, especially when the return gate was assumed to be closed. The sensitivity of simulations of lake water level to changing the Manning coefficient from 0.03 to 0.02 was -0.02 to $-0.18 \mathrm{~m}$ at high flows depending on lake water levels. The longitudinal cross section of water levels measured on 31/10/2017 between Balgavies lake $(\mathrm{H}=59.47 \mathrm{~m})$ and Milldens Weir $(\mathrm{H}=59.1)$ was simulated reasonably well (Nash-Sutcliffe coefficient $=0.52)$. Modelled estimates of the water levels at Milldens weir, using lookup tables from steady state simulations to identify weir water levels as a function of Balgavies Burn and lake outlet discharges, were reasonable at low water levels (Nash Sutcliffe Coefficient was $>0.5$ for observed weir water levels $<59.35 \mathrm{~m}$ ), but not at high water levels (Figure 3). The impact of the position of Milldens return gate on simulated water levels was most evident at very high water levels. The sensitivity of simulations of Milldens weir water level to changing of the value of the Manning coefficient from 0.03 to 0.02 was generally $<0.02 \mathrm{~m}$.

Very little additional impact of introduction of the tilting weir into the undredged channel was evident. However, there was a large impact of lade dredging on water levels in the lake at all except the very highest water levels $\left(\mathrm{H}_{\mathrm{L}}>60.0 \mathrm{~m}\right)$. The modelled periods when water level in Balgavies lake rose above $59.8 \mathrm{~m}$ decreased to 0 days and 20 days for 2014-2015 and 2015-2016 respectively. The base level in summer was also about $0.5 \mathrm{~m}$ lower.

The Balgavies lake water level exceedance curves (Figure 5a) showed that the modelled probability of the water level exceeding $59.8 \mathrm{~m}$ (the level when flooding of the road at Rescobie boathouse will occur) was reduced from a measured value of $3.0 \%$ ( $11 \mathrm{~d} /$ year) to $0.9 \%$ ( $3 \mathrm{~d} /$ year) by the dredging and marginally by the position of the Milldens return gate and the tilting weir. The impact of the gate/weir operation was larger at intermediate flows.

Our inference from this analysis is that channel dredging would be needed to achieve reduction in maximum lake water levels. The proposed tilting weir would contribute to maintain ing the dredged channel free of sediment in the longerterm.

\section{Modelling and measurements of flow through Chapel Mires spillway}

The proportion of flow passing over the Chapel Mires spillway, with potential impact on nutrient, sediment and water loading to the ecologically sensitive Chapel Mires, was influenced by the position of the Milldens return gate and the tilting weir (Figure 5b). The fraction of water travelling through the Chapel Mires spillway decreased with increasing discharge, and for a given discharge, the fraction decrease $d$ when the return gate was open, and further decreased when the tilting weir was open and when dredging occurred. Reduction in flowacross the Chapel Mires spillway was most marked for the dredged channel, with the tilting weir open, and located at the old spillway. The benefit of this reduction in flow through Chapel Mires spillway is less likelihood of nutrient-rich river flow into Chapel Mires mixing with the much less polluted water in the Chapel Mires, especially in the part protected by the culverted embankment on the southern edge of the wetlands ( Figure 2 and Supporting Information 1). High levels of sediment transport, which favour degradation of the Chapel Mire s vegetation, werelikely at high flows, while high levels of soluble P transport were likely to be associated with relatively low flows at the end of summer (Vinten et al., 2017).

In 2016-2017, measurements of the split of discharge from Balgavies lake down the Chapel Mires spillway and onwards down the mill lade, as a function of whether the Milldens return gate was open or closed, showed that the position of the existing return gate made a difference to the fraction of flow travelling via the Chapel Mires spillway. At such flows, with only the return gate open, the model simulated nearly all the flow passing over Chapel Mires spillway, but our observations showed only $37-90 \%$. This may reflect the presence of entrapped vegetation across the Chapel Mires spillway, increasing the resistance to flow across the spillway. Further information on the observed 
dynamics of flow can be found in Vinten et al. (2017), which suggested that the position of the Milldens return gate impacts discharge out of the lake, when $\mathrm{H}_{\mathrm{L}}>59.37 \mathrm{~m}$.

\section{Model vs observed simulations of flood risk and flows into Chapel Mires vs gate positions and dredging}

Under current lade bed conditions, introduction of a tilting weir with current common lade bed levels w ould only have a small impact on upstream flooding when levels in the lake are $<59.8 \mathrm{~m}$. This could be due to a backwater effect (Environment Agency, 2010) of the additional weir.

Upstream flood risk reduction by the proposed tilting weir occurs only at very high water levels $\left(\mathrm{H}_{\mathrm{L}}>60.2 \mathrm{~m}\right)$. While reducing such risk may be valuable, it occurs very infrequently, and at such levels further release of water may lead to undue risk of increasing the flood peak downstream. We therefore do not advocate the use of a tilting weir to relieve upstream flooding in these very high flow conditions until further analysis of downstream flooding impacts has been done.

The beneficial impact of dredging the common lade between the lake outlet and the Milldens weir on reduction of water levels in the lake under conditions where there is a risk of flooding, and on reducing the risk of high, sediment/nutrient laden flows into Chapel Mires, was clear. When dredging has taken place, the impact of the tilting weir, either at the site downstream of the bridge and upstream of the confluence of the Balgavies Burn, or at the site of the old, blocked spillway further upstream (see Figure 2), was greater, especially at water levels $>59.6 \mathrm{~m}$. However the additional direct benefit of the tilting weir on lake water levels still was quite small.

Operation of the tilting weir is useful in reduction of riverflow to Chapel Mires at times when it carries a large burden of sediment and nutrients. For example, in the most sensitive parts of Chapel Mires, water levels measured in May 2015 were $59.25-59.4 \mathrm{~m}$. Such water levels at Chapel Mires spillway are associated with lake outflow $>1 \mathrm{~m}^{3} / \mathrm{s}$, occurring about $9 \%$ of the time.

To maintain the benefit of dredging through time, a management scheme needs to consider how to deal with the future ingress of sediment. Instal lation of a tilting weir, or a manually operated weir gate with bed level around 58.6 $\mathrm{m}$ to promote flushing, was likely to be beneficial. In addition, adoption of management practices which control soil erosion in the catchment, as discussed in Vinten et al. $(2013,2017)$ should be encouraged.

\section{Ecological assessment}

\section{Vegetation survey of Chapel Mires}

The NVC habitat map for Chapel Mires (Fig. 5, Table 1) shows the presence of competitive, nutrient-and sedimenttolerant species such as Reed Canary Grass ( Phalaris arundinacea L.), Branched Burr Reed (Sparganium erectum L.) and Common Reed (Phragmites australis (Cav.) Steud.), which indicate spreading from the northern area close to the riverinto the more biodiverse sedge-rich southern areas).

The quadrats showed the presence of the Great Britain Red List species Lysimachia thrysifoliain the S27a areas but not in the northern quadrat located at the edge of the Phalaris arundinacea dominated area. Lysimachia thrysifolia would be affected by any $\mathrm{N}$-enrichment or by encroaching woodland as it requires high light levels. The vegetation composition of Q1 indicated a more or less infertile site with low levels of nitrogen; the quadrat Q3 is in an area of intermediate fertility/nitrogen levels and Q2 is intermediate to these two. The vegetation at Q1 and Q2 is characteristic of permanently wet sites while Q3 suggests damp but not wet soils. The vegetation data showed no evidence of any change in nutrients or water level between 2015 and 2017. The NVC communities probably most at risk of change were S27 which require high water and low nutrient levels. M9is the habitat most limited in its distribution at a national scale. It would be important to maintain a high water table in this area to prevent succession to woodland. Holaday et al (2015) noted that the upright sedge (Carex stricta Lam.) "appears to be 
adapted to tolerate low nitrogen availabil ity but cannot respond as rapidly and extensivelyas Phalaris arundinacea when nitrogen supply is high". Werner and Zedler (2002) noted that sedimentation reduces micro-topography of Carex tussocks making them vulnerable to invasion by Phalaris arundinacea. However it should also be noted $\left(O^{\prime}\right.$ Hare, pers.comm) that these species are a normal part of the assemblage in mesotrophic systems and may not be progressing in their extent.

The survey of the open water areas showed that Pond 2 (maximum depth $1.6 \mathrm{~m}$ ) was the largest and most diverse water body in the Chapel Mires site with eight aquatic macrophytes species recorded. The majority were characteristic eutrophicspecies (all of which have been recorded in Balgavies lake in recent years) although the presence of Bladderwort (a species aggregate of Utricularia australisand U. vulgaris) indicated more nutrient poor conditions (as did the presence of emergents e.g. Bottle Sedge (Carex rostrataStokes) and Bogbean). The western half of Pond 2 was dominated by the non-native Canadian Pondweed while the eastern half was co-dominated by both Canadian Pondweed and Hornwort. Pond 1 (maximum depth $2.5 \mathrm{~m}$ ) had a smaller surface area but a greater water depth than Pond 2 but lacked the two Potamogetonspecies and Elodea was rare. In the Inlet pond from the Lunan Water, Elodea canadensis was the dominant submerged plant species. Unlike Rescobie and Balgavies lakes, there was no evidence of cyanobacterial blooms in any of the sampled water bodies in the Chapel Mires site and water clarity was excellent with Secchi Disc readings of 2.20 recorded in Pond 1. Evidence of this better water quality was reflected in the lower PLEX scores calculated for Pond 2 and the other sampled waterbodies in the Chapel Mire site, compared with the PLEX scores recorded in the recent surveys of Rescobie and Balgavies lakes. More detail on this survey can be found in Gunn et al. (2017).

Our inference from this survey is that there is a gradient of trophic status of the wetlands in Chapel Mires, with the southernmost area, further from the river, being much less nutrient enrich ed. Someareas of encroachment by nutrient and sediment tolerant species in this southern section are a cause for concern, but ecological evidence of invasive processes is not available at present as the quadrats do not show significant change in species composition from 2015-2017.

\section{Water chemistry and end member mixing analysis}

Chemical analysis shows the western part of the small wetland has low al kal inity in summer but receives more alkalinity and $\mathrm{NaCl}$ in winter due to road runoff from the south west, partly reflected in the gully pot samples. The eastern part of the small wetland was quite pristine all year. Sediment $P$ was released in late summer in Pond 1 and in the western part of small wetland, but not in the eastern part of the small wetland. There was very little nitrate in the small wetland or pond 1 whereas a big difference between pond 1 and pond 2 occurred, the latter being close to or above Balgavies Burn nitrate concentrations. Alkalinity showed a clear north to south gradient in Chapel Mires (lake water $>$ inlet pond>pond 2>pond 1>small wetland).

The first two principal components explained $96.0 \%$ of the variation of the chosen solutes (Supporting Information 7). Balgavies lake outflow and rainfall formed two useful apices for EMMA. There was clearly a contribution from $\mathrm{Na}$ rich water contaminated by the road, but neither the gully pot or woodland pond candidates form ed a clear third apex for the Na rich water. It is possible that runoff from the south was not well represented by our sampling. We considered the point in the extreme bottom right of Supporting Information 7 as a potential end member representing runoff from the south of the site into the western part of the small wetland. We therefore carried out end member mixing analysis using this sample point as the third end member, together with the outermost values of the rainfall and Balgavies lake outflow samples to form the apices of a triangle. This enabled us to estimate proportions of water coming from the Lunan water downstream of Balgavies lake, rainfall and runoff from the south(Figure 6). Note those points in the wetland which showed no contribution from the Lunan Water are in the NVC S27a area to the south of the culvert which offers protection from incoming water to the north when water levels are low. Pond 2 had the highest proportion of lake water while pond 1 was intermediate. Neither of these 
varied greatly through the year, but the proportion of Lunan Water end member in the western part of the small wetland certainly did, with evidence that at high water levels $\left(\mathrm{H}_{\mathrm{L}}>59.5 \mathrm{~m}\right)$, there was more transfer of water from the north.

Our inference is that there are threats to the trophic condition of Chapel Mire sfom both the Lunan Water and from road contaminated runoff from the south. The relative importance of these threats varied with position in the wetland, with the western part of the small wetland influenced mainly by the road runoff from the south, espe cially in winter, but the eastern part being quite well protected, unless large events raise the water level in the lake to $>59.7 \mathrm{~m}$.

\section{Socio-economic assessment}

Survey - summary of results

Results from the survey of stakeholder attitudes showed an over-representation of older men (over 55) compared to the average age and gender balance in Angus. However, the data collected showed the diversity of perspectives on the proposed tilting weir and how these can the conflicting (Table 2).

The first stage in the analysis was to assess whether respondents feel concerned about the issues that the tilting weir aims to address: flood risk, low flows and wetland conservation. The level of concern for these issues might be a factor that can, in a second stage, explain the level of support measured for the scheme. Despite most respondents reporting not having previously experienced flooding in the Lunan Water catchment area, more than half stated being concerned or very concerned by this issue. However, most farmers were not concerned about restrictions on water abstraction (Table 2a) probably because none of them had experienced restrictions. This was also reflected in respondents preferred priorities for water management in the Lunan catchment. A large majority of respondents considered flood control should be a high priority of the water management strategy. Wetland conservation was a high priority for half of the respondents while most respondents gave a lower priority to abstraction issues.

When investigating the support for the installation of a tilting weir, we found that overall, the project received a good level of support (Table $2 \mathrm{~b}$ ), but there were disparities between farmers and residents. The farming community appeared particularly divided on this question, and the reasons for this were explored through the qualitative interviews.

To investigate further the level of support for the project, we analyse d the WTP stated by respondents (Table 2c). Overall, half of the respondents stated that they would be willing to pay to support the maintenance and operation of the weir after the end of the research project. $16 \%$ state $d$ that would not pay for it and $34 \%$ of the responses constituted protest answers (i.e. respondents who support and perceive benefits from the project, yet stated a null WTP as they disagree with the method of preference elicitation used or are concerned about fairness of the payment). We estimated an average WTP of about $£ 9.60$ (confidence interval: $€ 7.60$ and $£ 11.50$ ) per year per respondent over 10 years, and we can say with confidence that the average WTP is between $f 7.60$ and $£ 11.50$.

Finally we compared respondents' WTP under the different governance scenarios The results showed that the preferred governance scenario was local government management, with business governance ranked second and charity as least preferred option for most respondents.

The results highlighted two types of concern:

1. About the project itself, with $16 \%$ of respondents unwilling to pay anything towards the cost of managing water levels,

2. About the governance, illustrated by the high level of protest answers, due to either the lack of confidence that the project would be managed correctly under the proposed governance mechanism, or a belief that others should fund it, or a preference for another way of funding. 


\section{Post-surveyinterviews}

The benefits and dis-benefits, potential ways of managing the scheme, evidence for and against the scheme, gaps in governance of water management and farmer and land owners' rights and responsibilities, related to the proposed tilting weir scheme were discussed. Several interviewees stated they would like more detailed and accessible information about the scheme and its potential impacts. Interviewees whose knowledge of the scheme was based on the survey stated that they required more information to understand and assess the scheme for themselves. Others stated that more translation of the technical and scientific information about the scheme into accessible, non-scientific language, was desirable.

Interviewees identified institutional gaps in water management. For instance funding was available for capital investment in water management infrastructure such as flood defences but the perception was that there was less funding and institutional capacity for ongoing maintenance and management of this infrastructure. Some interviewees stated that this infrastructure was sometimes not effective without maintenance. There was also a clear regulatory process for installing capital infrastructure. The tilting weir scheme raised the issue of there being little precedent for managing schemes that required ongoing management e.g. adjusting the level of the tilting weir: of what kind of body would take responsibility for this, what the legal status would be and how decisions would be made. The status and management of structures such as weirs which had been installed before current legislation was in place was perceived as uncertain.

Interviewees expressed the view that landowners' and farmers' autonomy in water management had been reduced in recent decades. Landowners had less freedom to clear waterways and carry out other maintenance. For some this conflicted with farmers' identity as stewards of the land who had rights and responsibilities to maintain waterways. Here farmers' private interest was seen as largely compatible with the public good both because farmers produced food and because farmers and land owners were responsible agents who understood the consequences of their actions and had the local and technical expertise to carry out water management for the public good. For some this loss of autonomy meant a lack of maintenance of waterways, which was the cause of some of the flooding issues in the Lunan Water catchment.

For others, the current governance structure for clearing waterways and dredging prevented landowners acting in their own interests while causing water problems on other people's land, such as flooding downstream caused by dredging upstream, or damage to water quality. Private interests were not necessarily seen as compatible with the public good in relation to water management and regulation was needed to manage this dynamic.

Some interviewees expressed the view that natural flood management was preferable to engineering solutions in the Lunan Water catchment because it require d less ongoing management. "Nature" was seen as a force that would continue to shape water flows in the catchment and engineering solutions would be difficult to maintain if they did not accommodate this force. An engineering solution which required ongoing management was seen as susceptible to difficulties in relationships within the catchment: assembling people with enough time and energy to dedicate to managing a structure; accommodating conflicting views about how the structure should be managed; and finding people or an organisation willing to take re sponsibility for any negative impacts of the structure. In contrast natural solutions were seen by some as more autonomous and self-regulating and so requiring less energy from stakeholders and dispersing of responsibility for ongoing management.

In contrast, some framed the Lunan Water as a catchment which could not be considered "natural" as the waterways had undergone a lot of work such as straightening. In such a system natural management could requirea change which might lead to some people losing out through, for example, land being reconverted to flood plains. In an already artificial system, engineering and ongoing management may be required to maintain people's existing interests and assets. 
We infer from this work that while there were views expressed for and against the scheme, many stated that they did not benefit enough directly from the proposed scheme to take responsibility for its management and pursuing approval for its installation. Stakeholders were wary of the responsibility and energy this could involve without a clear belief in the benefits. The perceived presence of governance gaps was clear.

\section{General Discussion and Conclusions}

The work reported here attempts to reduce the uncertainty surrounding both the technical and socio-economic aspects of a proposed innovative approach to integrated water management. The proposed tilting weir can be seen as an attempted compromise between natural and engineered solutions, which also introduces a wider basis for governance than the status quo. The case study catchment, the Lunan Water, experiences issues that are common to catchments across the world (Ioris, 2012; Xia et al., 2016; Gooch and Stålnacke, 2010; Acreman et al., 2007; Fliervoet et al., 2017). In taking an integrated approach, we assert that it is better to achieve partial reduction in this uncertainty across a range of salient issues, rather than focus on reducing uncertainty about a single component which would satisfy a much narrower range of stakeholder concerns. The proposed water management intervention aimed to spread benefits across many water users in the catchment. However, in so doing we are challenging a philosophy of benign neglect, which may be beneficial to a narrower range of interests in the short term but lead to longer term lack of flexibility of water management, greater risk of impact of extreme events, and gradual, unheralded loss of aquatic biodiversity.

As we describe first steps in appraisal of a tilting weir to facilitate integrated water management, there are certain limitations of the hydrological modelling and other approaches we have used, which should be borne in mind when considering conclusions from the work. Firstly, we did not consider a full hydraulic calibration/validation exercise was warranted for this preliminary approach; rather we used a plausible value of the Manning coefficient (0.03) throughout the system and assessed model performance across the whole dataset. We took this approach because:

a) We were not modelling the full effect of the river flood plain, rather considering only flow within the confined channel and defined standing waters. Further work is now underway to model the flood plain as well, as opposed to only flow in the channel and defined surface waters. This work will al so model the unsteady nature of the flows directly, rather than using a series of steady state stage-discharge relationships to describe unsteady flowand water levels;

b) There is also uncertainty about appropriate flow inputs due to variable rainfall across the catchment and about other hydrological components such as ET and leakage to/from groundwater. The model used upscaling of $Q_{B}$ to generate the inflow to Balgavies lake, and if spatial variation of hydrological conditions across the catchment occurs, this may lead to significant discrepancies. A more rigorous hydrological model of flow inputs and associated uncertainty is also under development;

c) There was some uncertainty about when the return gate was closed over the time period, and in some cases the gate may also have been only partially closed;

Mitigation of reverse flow of water eg. from Balgavies Burn to the common lade will not be effectively modelled by the steady-state scheme, and for this reason too, a non-steady state approach is under development. Nonetheless, the steady-state approach we have used does give initial indications of the likely hydrological feasibility of the proposed scheme.

We also note that there is considerable debate on the appropriate way to manage inflows of water and nutrients into shallow wetlands to promote conservation of macrophyte-dominated, clear water ecology. However, there is evidence that this can be effective. For example, Špoljar et al. (2017) found that hydraulic treatment could be applied to regulate submerged macrophytes in shallow reservoirs, as an efficient and less inv asive approach than 
sediment removal, especially in sensitive karst areas; Green and Galatowitsch (2002) found that suppression of native sedges by $P$. arundinacea by high nitrate inputs occurred; Moss et al. (1986) explored the impact of isolating a previously mesotropic fen from inputs of nutrients which had caused it to degrade to a phytoplankton dominated state. Isolation initially brought about the desired improvement, although this was followed by a regression back to due to release of $P$ from lake sediments.

Further work, using a non-steady modelling approach, will address the issue of when such large burdens of nutrients and sediment occur, based on analysis of the lake outflow water quality and modelling of the mixing process with Chapel Mires.

We also note that dredging of water courses for sediment removal is the subject of strict regulation and may not be beneficial to river ecology and flood risk mitigation for other reasons (eg https://www.ciwem.org/policyreports/floods-and-dredging-a-reality-check). Further work can assess downstream flood risk impacts of more efficient release of water from Balgavies Lake at high flows, but the aim of the proposed scheme is to facilitate better management of potential storage in the lake.

We also note that the socio-economic survey was hampered by the small size of the catchment area. Given the resulting small sample size of the survey, the results obtained may not be representative of the catchment population. However they are insightful to illustrate the range of perspectives on the scheme and illustrate the concerns associated to its implementation at the catchment scale.

Bearing in mind these caveats, we draw some conclusions from the work described:

We have assessed the potential for a flexible hydraulic structure (tilting weir) and/or dredging, to contribute to adaptive management of water in an intensive arable catchment in Eastern Scotland. We have used an integrated approach comprising hydrological, ecological and socio-economic assessments, which could in future be included in an analysis of the potential for a Payments for Ecosystem Services scheme in the wider catchment.

Considering flood risk, there was a statistically significant upward trend in water levels in Balgavies lake from 2003. The flooding risk in Rescobie lake, upstream of Balgavies lake, is associated with public roads and housing and is considered as a concern by $62 \%$ of the survey and interview respondents. Flood risk reduction can be achieved by dredging the common lade downstream of Balgavies lake more effectively than by introducing the proposed tilting weir without dredging. However, to maintain the benefit of dredging over longer time periods, the introduction of a tilting weir would help prevent further sedimentation, as periodic opening would promote flushing of the lade.

As high flows in the main stem of the river introduce nutrient and sediment rich water to the wetland areas, a tilting weir could reduce the risk of wetland eutrophication. The rapid assessment of vegetation and the water chemistry mixing analysis demonstrated a clear gradient from nutrient rich sites near the main stem of the river associated with nutrient loving, sediment tolerant species (e.g. Phalaris arundinacea, Sparginum erectum, Phragmites australis) to more oligotrophic conditions and species associated with Carexwetlands. Except at high flows, the risk of nutrients and sediment from the river entering the wetland declines with distance away from the river. As the downstream river water quality has improved in recent years (Dunn et al., 2014), there is probably scope for more emphasis on protection of the Chapel Mires wetlands from eutrophication. For efficient wetland water quality management, a rule base for diversion of flows away from Chapel Mire s at critical times could be developed, using annual pattern of P loads from the lake, as described by May and Vinten (2018).

Probability of low flows to water users downstream of the lake has been dealt with elsewhere (Vinten et al., 2017). An economic impact of irrigation restriction was shown, but in the survey work reported in this paper, there was relatively little concern about the issue. However, recent regulatory work has also confirmed the river ecology in this catchment is impacted at low flows, and stricter regulation at low flows is envisaged (Leith, S., pers. comm., 2017, 2019). 
Apart from the technical uncertainties discussed above, a major area of concern is the issue of long-term governance. Practitioners and scientists can fall into a panacea trap, in which they falsely assume that all governance issues can be reduced to a set of models, in which preferences and perceptions of stakeholders are similar (Ostrom 2007). Views in favour of and against the proposed "Water for all" scheme were expressed by respondents to the survey and the interviews. Among those in favour there were no clear champions of the scheme who were willing to dedicate time and energy to pursuing approval for its installation and managing the tilting weir after installa tion. Stakeholders did not feel they benefited enough directly from the scheme to champion it. There was also some uncertainty about how the scheme would work and the science behind it. Gaps in the governance of water manage ment and a lack of precedence for managing such a scheme also created uncertainty. There was also a feeling that water issues can cause conflict, which would create difficulties in the long-term management of the scheme. Several stakeholders felt that the scheme also did not address the root of water management problems which were identified by some as sediment runoff from farms (Vinten et al., 2013, 2017; Balana et al., 2012) into water ways, or a lack of ongoing water management processes such as dredging.

The economic benefits of managing high and low flows could be integrated into novel approaches to governance (e.g. community interest company or drainage board), and hence help support the non-market benefits of wetland conservation. The development of statutory multi-stakeholder groups, which can respond in both an integrated and adaptive manner to water management challenges is seen as a constructive way forward for water issues in this and other similar catchments.

Formal institutions for long-term governance of water for multiple stakeholder interests at catchment scale are quite rare in Scotland (Rouillard et al., 2013), compared with other countries with a long history of managing irrigation water (Gooch and Stålnacke, 2010). Policy actors have been constrained by the "nested" nature of advisory groups. However, salient examples include Loch Leven, where sluice gates are managed to meet the demands of downstream industry (Binnie and Partners, 1965) and to maintain minimum environmental flows in the River Leven. The Pow of Inchaffray, a tributary of the River Earn, has been the subject of a recent Bill for Scotland's only local drainage commissioners (Association of Drainage Authorities, 2017a) to enable collection of a levy from catchment heritors for maintenance of drainage and oversight of flood risk reduction. Such schemes are more frequent in England, for example in the drained fenlands in England (Association of Drainage Authorities, 2017b), and in larger scale river systems elsewhere (e.g. Gooch and Stålnacke, 2010; Wescoat, Siddiqi and Muhammad, 2018; Fliervolt, van den Born and Meijerink, 2017), the challenge of collaborative governance of river basin projects is recognised.

Rouillard et al (2013) advocate the development of statutory multi-stakeholder groups, which can respond in both an integrated and adaptive manner to water management challenges. Given that Scotland is developing a Hydro Nation strategy (Water Resources (Scotland) Act (2013)), it is perhaps appropriate that achieving a wider balance of interests and benefits across water users should be further developed in this research catchment, and this study has helped to identify some of the technical and socio-economic barriers to innovation and adaptive water management for flood risk and aquatic conservation.

The findings of this work can contribute to an integrated model of the system, to identify how to manage flows with an artificial tilting weir to achieve both flood risk reduction and wetland conservation. A pilot project, where a tilting weir is installed for a fixed period of time to monitor impacts and develop management approaches would be beneficial. To be useful for flood risk management, forecasting of water levels and the impact of management is required. This is being explored through a conceptual rainfall-runoff coupled with a lake storage model (Pohle and Vinten, 2018) which can be applied for simulations under seasonal forecasts (e.g. Saha et al., 2014) and climate scenarios and thus assessment of long-term effects of management decisions. Future work will also explore alternative management options and sites for tilting weir installation. 


\section{Acknowledgements}

We thank Scottish Government (SEFARI) for funding this work. We thank riparian owners in the upper Lunan catchment for access to land and water for sampling and monitoring, as well as for hel pful ongoing discussions. and Natural Environment Research Council for flow data and public registry for abstraction licence data. We also thank Scottish Natural Heritage (SNH)for provision of advice and wetland data, Scottish Environment Protection Agency (SEPA) for advice re consenting, and Scottish Wildlife Trust for lake water level data. We thank Janice Corrigan of Angus Council for convening a stakeholder group to oversee the project, and we thank Peter McPhail (SNH), Scott Leith (SEPA), Hugh Ingram, Alban Houghton and Rab Potter (Scottish Wildlife Trust), Professor Alan Werritty (Dundee University), Marshall Halliday and Craig McIntyre (Esk Rivers and Fisheries Trust) for constructive advice and participation in the project steering group. We also thank Peter McPhail for practical support and advice on NVC classification of the vegetation in Chapel Mires and supply of information from SNH da ta sources. We thank Jackie Potts of Biomathematics and Statistics Scotland for statistical support. Permission was obtained from the James Hutton Institute research ethics committee to carry out interviews. 


\section{References}

Acreman, M. C., Fisher, J., Stratford, C. J., Mould, D. J., Mountford, J. O. 2007. Hydrological science and wetland restoration: some case studies from Europe. Hydrol. Earth Syst. Sci. 11, 158-169, https://doi.org/10.5194/hess-11158-2007.

Acreman, M. C., Blake, J. R., Booker, D. J., Harding, R. J., Reynard, N., Mountford, J. O., Stratford, C. J. 2009. A simple framework for evaluating regional wetland ecohydrological response to climate change with case studies from Great Britain. Ecohydrology, 2, 1-17. https://doi: 10.1002/eco.37

Aquatic Control Engineering 2004. Project: Somerset Levels Sluice Refurbishments https://www.aquaticcontrol.co.uk/wp-content/uploads/2017/09/Somerset-Levels-Sluice-Refurbishments.pdf [June 2018].

Association of Drainage Authorities. 2017a. https://www.ada.org.uk/2017/11/bill-scotlands-local-drainagecommissioners-progresses-scottish-parliament/[June 2018]

Association of Drainage Authorities. 2017b. https://www.ada.org.uk/member_type/idbs/ [June2018]

Balana, B. B., Lago, M., Baggaley, N., Castellazzi, M., Sample, J., Stutter, M., ... Vinten, A.J.A. 2012. Integrating Economic and Biophysical Data in Assessing Cost-Effectiveness of Buffer Strip Placement. J. Environ. Qual. 41, 380. https://doi.org/10.2134/jeq2010.0544

Binnie and Partners 1965. Report on the regulation of discharges from Loch Leven, Fifeshire. Binnieand Partners, Chartered Civil Engineers, Artillery House, London SW1. October 1965. 30pp.

Bino, G., Sisson, S. A., Kingsford, R. T., Thomas, R. F. and Bowen, S. 2015. Developing state and transition models of floodplain vegetation dynamics as a tool for conservation decision-making: a case study of the Macquarie Marshes Ramsar wetland. J. Appl. Ecol. 52, 654-664. https://doi:10.1111/1365-2664.12410

Bizzi, S., Pianosi, F., Soncini-Sessa, R. (2012). Valuing hydrological alteration in multi-objective water resources management, J. Hydrol., 472-473, 277-286. https://doi.org/10.1016/j.jhydrol.2012.09.033.

Bragg, O.M., Hulme, P.D., Ingram, H.A.P., Johnston, J.P., Wilson, A.I.A. 1994. A maximum-minimum recorderfor shallow water tables, developed for ecohydrological studies on mires. J. Appl. Ecol. 31,589-592.

Brouwer, R., van Ek, R. 2004. Integrated ecological, economic and social impact assessment of alte rnative flood control policies in the Netherlands. Ecol. Econ. 50, 1-21.

Carson, R. T. 2000. Contingent valuation: A user's guide. Environ. Sci. Technol. 34, 1413-1418. https://doi.org/10.1021/es990728j

Christopherson, N., Hooper, R. P. 1992. Multivariate analysis of stream water chemical data: the use of principal components analysis for the end-member mixing problem. Water Resour. Res. 28, 99-107

Coops, H., Hosper, S.H. 2002. Water-level Management as a Tool for the Restoration of Shallow Lakes in the Netherlands, Lake. Reserv. Manag., 18 (4), 293-298. DOI: 10.1080/07438140209353935

Covino, T. 2017. Hydrologic connectivity as a framework for understanding biogeochemical flux through watersheds and along fluvial networks, Geomorphology 277, 133-144.

Duigan, C., Kovach, W., Palmer, M. 2007. Vegetation communities of British lakes: A revised classification scheme for conservation. Aquat.Conserv. 17, 147-173. https://doi.org/10.1002/aqc.780 
Dunn, S. M., Sample, J., Potts, J., Abel, C., Cook, Y., Taylor, C., Vinten, A. J. A. 2014. Recent trends in water quality in an agricultural catchment in Eastern Scotland: elucidating the roles of hydrology and land use. Environ. Sci.- Proc. Imp. 16, 1659-1675. https://doi: 10.1039/C3EM00698K

Ellenberg, H., Düll, R., Wirth, V., Werner, W. Paulißen, D. 1991. Zeigerwerte von Pflanzen in Mitteleuropa, 2nd edn. Verlag Erich Goltze KG, Göttingen. Scripta Geobotanica.

EnviroCentre 2014. Lunan Water Catchment Study, Draft Report, prepared for Esk Rivers and Fisheries Trust. http://wwwerftorguk/

Environment Agency 2010. Fluvial Design GuideChapter 7. http://evidence.environmentagency.gov.uk/FCERM/en/FluvialDesignGuide/Chapter7.aspx?pagenum=4 [June 2018].

Environment Agency 2016. Design, operation and adaptation of reservoirs for flood storage: report. Ref: ISBN 978-184911-383-0, SC120001/R, 188 pages

Fliervoet, J.M., van den Born, R.J.G. Meijerink, S.V. 2017. A stakeholder's evaluation of collaborative processes for maintaining multi-functional floodplains: a Dutch case study. International Journal of River Basin Management 15, 175-186.

Gilvear, D.J., Spray C.J., Mulet-Casas, R. 2013. River rehabilitation for the delivery of multiple ecosystem services at the river network scale. J Environ. Manage. 126, 30-43.

Gooch, G., Stålnacke, P. (eds). 2010. Science, policy and stakeholders in water management: an integrated approach to river basin management. Earthscan Ltd., London. ISBN 978-1-84407-919-3

Green, E. K., Galatowitsch, S. M. (2002). Effects of Phalaris arundinacea and nitrate-N addition on the establishment of wetland plant communities. J. of Appl. Ecol. 39,134-144. doi:10.1046/j.1365-2664.2002.00702.x

Grieve, I. C., Gilvear, D. J. 1994. Quantifying anthropogenic nutrient sources and loadings within a small catchment with conservation interests, eastern Scotland. Aquatic Conserv: Mar. Freshw. Ecosyst., 4, 273-287. doi:10.1002/aqc.3270040307

Guan, L. Lei, J., Zuo, A., Zhang, H. Lei, G., Wen, L. 2016. Optimizing the timing of water level recession for conservation of wintering geese in Dongting Lake, China. Ecol. Eng. 88, 90-98

https://doi.org/10.1016/j.ecoleng.2015.12.009.

Gunn, I., O'Hare, M., Olszewska, J. 2017. Review Of The Aquatic Ecology Of The Lunan Water System: RESAS PESLES Project - Contribution To Report D3a, October 2017.

http://www.hutton.ac.uk/sites/default/files/files/Paper\%20D\%20\%20Review\%20of\%20aquatic\%20ecology\%20D3a \%200ct\%202017\%20Gunn\%20et\%20al.pdf (last access 10/5/18)

HECRAS. 2016. Hydrological Engineering Center River Analysis Software 5.0.1

http://www.hec.usace.army.mil/software/hec-ras/ [June 2018]

Holaday A.S., Schwilk, D.W., Waring, E.F., Guvvala, H., Griffin, C.M., Lewis, O.M. 2015. Plasticity of nitrogen allocation in the leaves of the invasive wetland grass, Phalaris arundinacea and co-occurring Carex species determines the photosynthetic sensitivity to nitrogen availability. J. Plant Physiol. 177, 20-29.

Höllermann, B., Evers, M. 2017. Perception and handling of uncertainties in water management -A study of practitioners' and scientists' perspectives on uncertainty in their daily decision-making. Environ. Sci. Pol., 71, 9-18. https://doi.org/10.1016/j.envsci.2017.02.003 
Hooper, R. 2016. End Member Mixing Analysis spreadsheet, HydroShare, http://www.hydroshare.org/resource/9ad1ebc69e9a4eda948ecd33155aae4c

Ioris, A.A.R. (ed). 2012. Tropical Wetland Management: The South-American Pantanal and the International Experience Ashgate: Farnham, Surrey

Jing, L., Lu, C., Xia, Y., Shi, L., Zuo, A., Lei, J., Zhang, H., Lei, G., Wen, L. 2017. Effects of hydrological regime on development of Carex wet meadows in East Dongting Lake, a Ramsar Wetland for wintering waterbirds. Sci. Rep. 7, 41761. https://doi:10.1038/srep41761

Kearney, M. S., Riter, J.C.A., Turner, R.E. 2011. Freshwater river diversions for marsh restoration in Louisiana: Twenty-sixyears of changing vegetative cover and marsh area, Geophys. Res. Lett. 38, L16405, https://doi: 10.1029/2011GL047847.

Kingsford, R.T. 2000. Ecological impacts of dams, water diversions and river management on floodplain wetlands in Australia. Austral. Ecol. 2000. 25, 109-127

Lamers, L. P. M., Vile, M. A., Grootjans, A. P., Acreman, M. C., van Diggelen, R., Evans, M. G., Smolders, A. J. P. 2015. Ecological restoration of rich fens in Europe and North America: from trial and error to an evidence -based approach. Biol. Rev. Camb. Phil. 90, 182-203. https://doi.org/10.1111/brv.12102

Martin-Ortega, J., Ojea, E., Roux,C. 2013. Payments for Water Ecosystem Services in Latin America: a literature review and conceptual model. Ecosyst. Serv. 6, 122-132

May, L., Vinten, A.J.A. 2018. Assessment of water quality changes in Lunan Lakes. Report for Scottish Government.

Meert, P.; Willems, P.; Nossent, J., Vanderkimpen, P., Pereira, F., Verwaest, T., Mostaert, F. (2016). Development of conceptual models for an integrated catchment management: Subreport 3 - Construction and calibration of conceptual river models. Version 4.0. WL Rapporten, 00_131. Flanders Hydraulics Research: Antwerp, Belgium. Available from: https://www.researchgate.net/publication/316879905_[accessed Apr 02 2019].

Moss B., Balls H., Irvine K., Stansfield J. (1986) Restoration of two lowland lakes by isolation from nutrient-rich water sources with and without removal of sediment. J. Appl. Ecol., 23, 391-414

Muradian, R., Corbera, E., Pascual, U., Kosoy, N., May, P.H. 2010. Reconciling theory and practice: An alternative conceptual framework for understanding payments for environmental services. Ecol. Econ. 69, 1202-1208.

Nash, J. E., Sutcliffe, J. V. 1970. River flow forecasting through conceptual models part I - A discussion of principles. J. Hydrol. 10, 282-290. https://doi.org/10.1016/0022-1694(70)90255-6

National Library of Scotland. 2006. http://maps.nls.uk/bathymetric/chart/2006.[4June 2018].

Ncube, S., Spray, C., Geddes, A. 2018. Assessment of changes in ecosystem service delivery-a historical perspective on catchment landscapes, Int. J. Biodiv. Sci. Ecosyst. Serv. Manag. 14, 145-163, DOI:

10.1080/21513732.2018.1489306

NERC. 2018. River Flow Archive. http://www.ceh.ac.uk/data/nrfa/data/station.html?13005) [June2018]

O'Connell P.E., Ewen, J., O'Donnell, G.M., Quinn, P.F. 2007. Is there a link between agricultural land -use management and flooding? Hydrol. Earth Syst. Sci. 11, 96-107.

Ó Dochartaigh, B.É., Macdonald, A.M., Fitzsimons, V., Ward, R. 2015. Scotland's aquifers and groundwater bodies. British Geological Survey Open Report, OR/15/028. 76pp. 
Ostrom, E. 2007. A diagnostic approach for going beyond panaceas. Proc. Nat. Acad. Sci. 104, 15181-15187. https://doi: 10.1073/pnas.0702288104

Parajka, J., Merz, R., Blöschl, G. 2007. Uncertainty and multiple objective calibration in regional water balance modelling: case study in 320 Austrian catchments. Hydrol. Proc. 21, 435-446. https://doi.org/10.1002/hyp

Pohle, I.,Vinten, A. 2018. Modellierung als Grundlage für Entscheidungsprozesse im Wassermanagement in einem agrarisch geprägten Einzugsgebiet. Conference Contribution. Tag der Hydrologie, Dresden, March 2018.

Rodwell, J.S. (ed.) 1995. British Plant Communities. Volume 4. Aquatic communities, swamps and tall -herb fens. Cambridge University Press.

Rouillard,JJ, Heal, K.V., Ball, T., Reeves., A.D. 2013. Policy integration for adaptive water governance: Learning from Scotland's experience, Environ. Sci. Pol. 33, 378-387.

Saha, S., Moorthi, S., Wu, X., Wang, J., Nadiga, S., Tripp, P., ... Becker, E. 2014. The NCEP Climate Forecast System Version 2. J. Climate 27, 2185-2208. https://doi.org/10.1175/JCLI-D-12-00823.1

Shortall, O., Rear, L., Vinten, A.J.A., Novo, P., Kuhfuss, L. 2017. Water management issues in the Lunan water: Results from 2014 stakeholder interviews.

http://www.hutton.ac.uk/sites/default/files/files/Leaflet\%20output\%20LR\%20work.pdf

Špoljar, M., Zhang, C., Dražina, T., Zhao, G., Lajtner, J., Radonić, G. (2017). Development of submerged macrophyte and epiphyton in a flow-through system: Assessment and modelling predictions in interconne cted reservoirs, Ecolog. Ind., 75, 145-154. https://doi.org/10.1016/j.ecolind.2016.12.038.

Turner, R.K., van den Bergh, J.C.J.M., Söderqvist, T., Barendregt, A., van der Straaten, J., Maltby, E. van lerland, E.C. 2000. Ecological-economic analysis of wetlands: scientific integration for management and policy. Ecol. Econ. 35, 723.

Turner,E.R., Bodker, J.E., Schulz, C. 2018. The belowground intersection of nutrients and buoyancy in a freshwater marsh. Wetl. Ecol. Manag. 26, 151-159. https://doi.org/10.1007/s11273-017-9562-y

Vinten, A.J.A., Martin-Ortega, J., Glenk, K., Booth, P., Balana, B.B., MacLeod, M., Lago, M., Moran, D., Jones, M. 2012. Application of the WFD cost proportionality principle to diffuse pollution mitigation: a case study for Scot tish Lochs, J. Environ. Manag. 97, 28-37.

Vinten, A.J.A., Loades, K., Addy, S. Abel, C., Richards, S., Stutter, M., Cook, Y., Watson, H., Taylor, C. Baggaley, N., Ritchie, R. 2013. Assessment of the use of filter fences for erosion control in the afterm ath of potatoes on sloping land in Eastern Scotland. Sci. Tot. Environ. 468-469, 1234-1244.

Vinten, A.J.A., Sample, J., Ibiyemi, A., Abdul-Salam, Y., Stutter, M. 2017. A tool for cost-effectiveness analysis of field scale sediment-bound phosphorus mitigation measures and application to analysis of spatial and temporal targeting in the Lunan Water catchment, Scotland. Sci. Tot. Environ. 586, 631-641.

Vinten A.J.A, Wilkinson, M., Sample J.E., Rear L., Hoang-Cong, C., Novo, P., Halliday, M. 2017. Water level management in the upper Lunan Water, Angus, Scotland: threat or opportunity for improved delivery of water ecosystem services? Report for 3rd Lunan Catchment Management Group Meeting, April 2017. http://www.hutton.ac.uk/sites/default/files/files/Lunan\%20Water\%20Managementv12.pdf

Water Resources (Scotland) Act 2013. http://www.legislation.gov.uk/asp/2013/5 [June 2018]

Werner, K.J., Zedler, J.B. 2002. How sedge meadow soils, microtopography, and vegetation respond to sedimentation. Wetlands 22,451-466. 
Werritty, A. 2006. Sustainable flood management: oxymoron or new paradigm? Area, 38, 16-23. https://doi:10.1111/j.1475-4762.2006.00658.x

Wescoat, J. L., Jr., Siddiqi, A., Muhammad, A. 2018. Socio-hydrology of channel flows in complex river basins: Rivers, canals, and distributaries in Punjab, Pakistan. Wat Resour. Res. 54. https:// doi.org/10.1002/2017WR021486

Wilkinson, M.E., Quinn, P.F., Barber, N.J., Jonczyk, J. 2014. A framework for managing runoff and pollution in the rural landscape using a Catchment Systems Engineering approach. Sci. Tot. Environ. 468-469, 1245-1254.

Xia, S., Liu, Y., Wang, Y., Chen, B., Jia, Y., Liu, G., Yu, X., Wen, L. 2016. Wintering waterbirds in a large river floodplain: Hydrological connectivity is the key for reconciling development and conservation. Sci. Total Environ. 573, 645-660. 


\section{Figures}

Figure 1. Overview of the Lunan Water catchment showing the main non-agricultural areas (MASTER MAP coverage), the bounds of the upper Lunan Water catchment considered in this study, and the lake outlet zone where the hydraulic model was developed. UTMco-ordinate system.

Figure 2. Detail of exit zone of Balgavies Loch and Chapel Mires pertinent to steady state hydraulic model. Minimum Bed levels (in $\mathrm{m}$ above sea level) shown in red. CMS=Chapel Mires Spillway, RET=Return gate from Milldens lade to Lunan Water, TiW= possible sites for tilting weir. Note that the more westerly of these two is at the site of a blocked off former spillway. Note that the tailwater channel (Lunan Water) is not included in the steady state model used in this paper. More information on the section of the uppe r Lunan Water catchment downstream of Balgavies lake, including common lade, Milldens weir, Milldens lade, spillways and tailwaters, in the area downstream of the outlet to Balgavies lake, showing positions of proposed tilting weir and penning structure is given in supporting information 1 and 2 .

Figure 3. Hourly water level data collected at Balgavies lake inlet (2014-2018) compared with modelled Balgavies lake levels under current management and with tilting weir+dredging. Also shows water levels at Res cobie Lake and Milldens Weir, discharge from Balgavies Burn into common lade and modelled water levels at Balgavies lake and $\mathrm{u} / \mathrm{s}$ of Milldens weir.

Figure 4. Rapid appraisal of UK National Vegetation Classification (Rodwell, 1995) of terrestrial wetland are as of Chapel Mires. Survey June 2017. Total area of Chapel Mires is $0.11 \mathrm{~km}^{2}$

Figure 5. (a). Water level exceedance curves for Balgavies lake - observed compared with modelled values for March 2015-Nov 2017. (b) HECRAS simulations of the split of flow between Chapel Mires spillway and continuation down the common lade with different weir settings and dredging assumptions.

Figure 6. Estimation of the contribution of the Lunan waterd/s of Balgavies to the composition of samples in Chapel Mires wetland using EMMA. Also shown is the Balgavies lake water level, and the water level in a dipwell at the culvert between the small wetland and the ponds in Chapel Mires (Figure 5). 


\section{Tables}

Table 1. Species lists and percentage cover for 4x4m quadrats Q1 and Q2 (Figure 5) taken in Chapel Mires in 2015 and 2017. Note total cover may be $>100 \%$ due to overlapping vegetation or $<100 \%$ due to open water. Species scored as $<1=$ present but at less than $1 \%$ cover, $0=$ had been present but could not be found, $+=$ present outside boundaries of quadrat, ? = identification uncertain, species may be present. Other quadrat sampling data can be found in Vinten et al. (2017).

\begin{tabular}{|c|c|c|c|c|c|c|c|c|c|}
\hline \multirow[t]{2}{*}{ Species } & \multicolumn{3}{|c|}{$\begin{array}{l}\text { Quadrat 1 S27a East Carex } \\
\text { rostrata } 354103750403\end{array}$} & \multicolumn{3}{|c|}{$\begin{array}{l}\text { Quadrat } 2 \text { S27a West Carex } \\
\text { rostrata } 35395735040\end{array}$} & \multicolumn{3}{|c|}{$\begin{array}{l}\text { Quadrat } 3 \text { W3/S28 Phalaris } \\
\text { arundinacea } 353813 \\
750739\end{array}$} \\
\hline & $\begin{array}{l}\text { May- } \\
2015\end{array}$ & $\begin{array}{l}\text { Jul- } \\
2015\end{array}$ & $\begin{array}{l}\text { Jun- } \\
2017\end{array}$ & $\begin{array}{l}\text { May- } \\
2015\end{array}$ & $\begin{array}{l}\text { Jul- } \\
2015\end{array}$ & $\begin{array}{l}\text { Jun- } \\
2017\end{array}$ & $\begin{array}{l}\text { May- } \\
2015\end{array}$ & $\begin{array}{l}\text { Jul- } \\
2015\end{array}$ & $\begin{array}{l}\text { Jun- } \\
2017\end{array}$ \\
\hline Creeping Bent (Agrostis stolonifera L.) & $<1$ & & 0 & & & & & & \\
\hline Brown Sedge (Ca rex disticha Huds.) & & $<1$ & 1 & & & & & & \\
\hline Grea ter Tussock-Sedge (Carex paniculata L.). & & & & & & & 1 & 1 & 2 \\
\hline Bottle Sedge (Carex rostrataStokes) & $<1$ & $<1$ & 1 & 5 & 20 & 8 & & & \\
\hline Carexsp. & $<1$ & & & & & & & & \\
\hline Jointleaf Rush (Juncus articulates L.) & 1 & $<1$ & 3 & $<1$ & 1 & 2 & & & \\
\hline Reed Ca nary Grass ( Phalaris arundinacea L.) & & & & & & & 40 & 50 & 50 \\
\hline Sparganiumsp. & & & & & & & $<1$ & 2 & $<1$ \\
\hline Wild Angelica (Angelica sy/vestrisL.) & & & & & & & & $<1$ & \\
\hline Mars h Marigold (Caltha palustrisL.) & & & & & & & + & & 0 \\
\hline $\begin{array}{l}\text { Opposite-Leave Golden Saxifrage } \\
\text { (Chrysos plenium oppositifolium L.) }\end{array}$ & & & & & & & $<1$ & $<1$ & 0 \\
\hline Cowbane (Cicuta virosa L.) & 3 & 15 & 1 & $<1$ & 2 & 1 & & & \\
\hline Marsh Cinquefoi (Comarumpalustre L.) & $<1$ & 3 & $<1$ & $<1$ & $<1$ & $<1$ & & & \\
\hline Fringed Willowherb (Epilobium ciliatum Raf.) & & & & 4 & 4 & 4 & $<1$ & $<1$ & $<1$ \\
\hline Marsh Willowherb (Epilobium palustre L.) & 2 & & 2 & 4 & 10 & 0 & & & \\
\hline $\begin{array}{l}\text { Mea dowsweet ( Filipendula ulmaria (L.) } \\
\text { Maxim.) }\end{array}$ & & & & & & & 15 & 35 & 15 \\
\hline $\begin{array}{l}\text { Common Marsh Bedstraw (Galiumpalustre } \\
\text { L.) }\end{array}$ & & & & 3 & & 8 & 3 & 1 & 3 \\
\hline Yellow Iris (Iris pseudacorus L.) & 4 & 5 & 10 & 25 & 40 & 30 & $<1$ & & $<1$ \\
\hline Common Duckweed ( Lemna minorL.) & 3 & 1 & $<1$ & 1 & $<1$ & $<1$ & & & \\
\hline Tufted Loosestrife (Lysimachia thyrsiflora L.) & 20 & 20 & 30 & & 1 & & & & \\
\hline $\begin{array}{l}\text { Bogbean (Menyanthestrifoliate L.) } \\
\text { Forget-Me-Not (Myosotissp.) }\end{array}$ & 25 & 48 & 40 & $\begin{array}{l}5 \\
<1\end{array}$ & 10 & $\begin{array}{l}5 \\
<1\end{array}$ & 2 & & 2 \\
\hline $\begin{array}{l}\text { Water Forget-Me-Not (Myosotis scorpioides } \\
\text { L.) }\end{array}$ & & & & 1 & 1 & 2 & $<1$ & 1 & $<1$ \\
\hline Bog Myrtle (Myrica galeL.) & $<1$ & 1 & $<1$ & & & & & & \\
\hline $\begin{array}{l}\text { Bog Pond weed ( Potamogeton polygonifolius } \\
\text { Pourret) }\end{array}$ & 8 & 10 & 3 & & & & & & \\
\hline Common nettles (Urtica dioca L.) & & & & & & & $<1$ & 1 & $<1$ \\
\hline Field Horsetail (Equisetum c.f. arvense L.) & & & & & & & & $<1$ & $<1$ \\
\hline Water Horsetail (Equisetum fluviatile L.) & $<1$ & $<1$ & 3 & $<1$ & 2 & $<1$ & $<1$ & & 0 \\
\hline $\begin{array}{l}\text { Rough-Stalked Feather-Moss (Brachythecium } \\
\text { rutabulum (Hedw.) Bruch, Schimp. and } \\
\text { W.Guembel) }\end{array}$ & & & & & & & ? & & \\
\hline $\begin{array}{l}\text { Calliergon Moss (Calliergon cordifolium } \\
\text { (Hedw.) Kindb.) }\end{array}$ & & & & 30 & & 40 & ? & & 1 \\
\hline $\begin{array}{l}\text { Pointed Spear-Moss (Calliergonella cuspidate } \\
\text { (Hedw.) Loeske) }\end{array}$ & & & & $<1$ & & $<1$ & & & \\
\hline $\begin{array}{l}\text { Cyprus-Leaved Plaitmoss (Hypnum } \\
\text { cupressiforme Hedw.) }\end{array}$ & & & & & & & ? & & $?$ \\
\hline Bla dderwort (Utricularia vulgaris agg.) & $<1$ & & & & & & & & \\
\hline Common Alder (Alnus g/utinosa (L.) Gaertn.) & & & & & & & + & & $<1$ \\
\hline
\end{tabular}


Table 2. Responses to interviews with stakeholders about "Water for all" project.

\begin{tabular}{|c|c|c|c|}
\hline \multicolumn{2}{|c|}{ Concern regarding flooding } & \multicolumn{2}{|c|}{ Concern regarding abstraction } \\
\hline & $\begin{array}{l}\text { Number of } \\
\text { respondents }\end{array}$ & & Number of farmers \\
\hline Not concerned at all & 9 & Not concerned at all & 3 \\
\hline Not very concerned & 12 & Not very concerned & 2 \\
\hline Neutral & 10 & Neutral & 2 \\
\hline Concerned & 34 & Concerned & 1 \\
\hline Very concerned & 6 & Very concerned & 2 \\
\hline TOTAL & 71 & & \\
\hline \multicolumn{4}{|c|}{ b. Should the project be implemented? } \\
\hline & $\begin{array}{l}\text { Number of } \\
\text { respondents }\end{array}$ & $\begin{array}{l}\text { Of which are } \\
\text { residents }\end{array}$ & $\begin{array}{l}\text { Of which are } \\
\text { farmers }\end{array}$ \\
\hline Definitely not & 6 & 2 & 4 \\
\hline Probably not & 5 & 3 & 2 \\
\hline $\begin{array}{l}\text { Don't know/no } \\
\text { opinion }\end{array}$ & 11 & 10 & 1 \\
\hline Probably & 35 & 31 & 4 \\
\hline Definitely & 16 & 15 & 1 \\
\hline TOTAL & 73 & 61 & 12 \\
\hline \multicolumn{4}{|c|}{ c. Willingness to pay to support project } \\
\hline f0 & $>£ 0$ & \multicolumn{2}{|c|}{ Protest $\mathbf{f 0}$} \\
\hline $16 \%$ & $50 \%$ & \multicolumn{2}{|c|}{$34 \%$} \\
\hline \multicolumn{2}{|c|}{$\begin{array}{l}\text { Mean WTP: } £ 9.60 \text { / year over } 10 \text { years } \\
\text { Confidence intervala: }[£ 7.60 ; £ 11.50]\end{array}$} & & \\
\hline
\end{tabular}

a: Confidence interval estimated by bootstrapping using the bias corrected method and 1000 replications. 


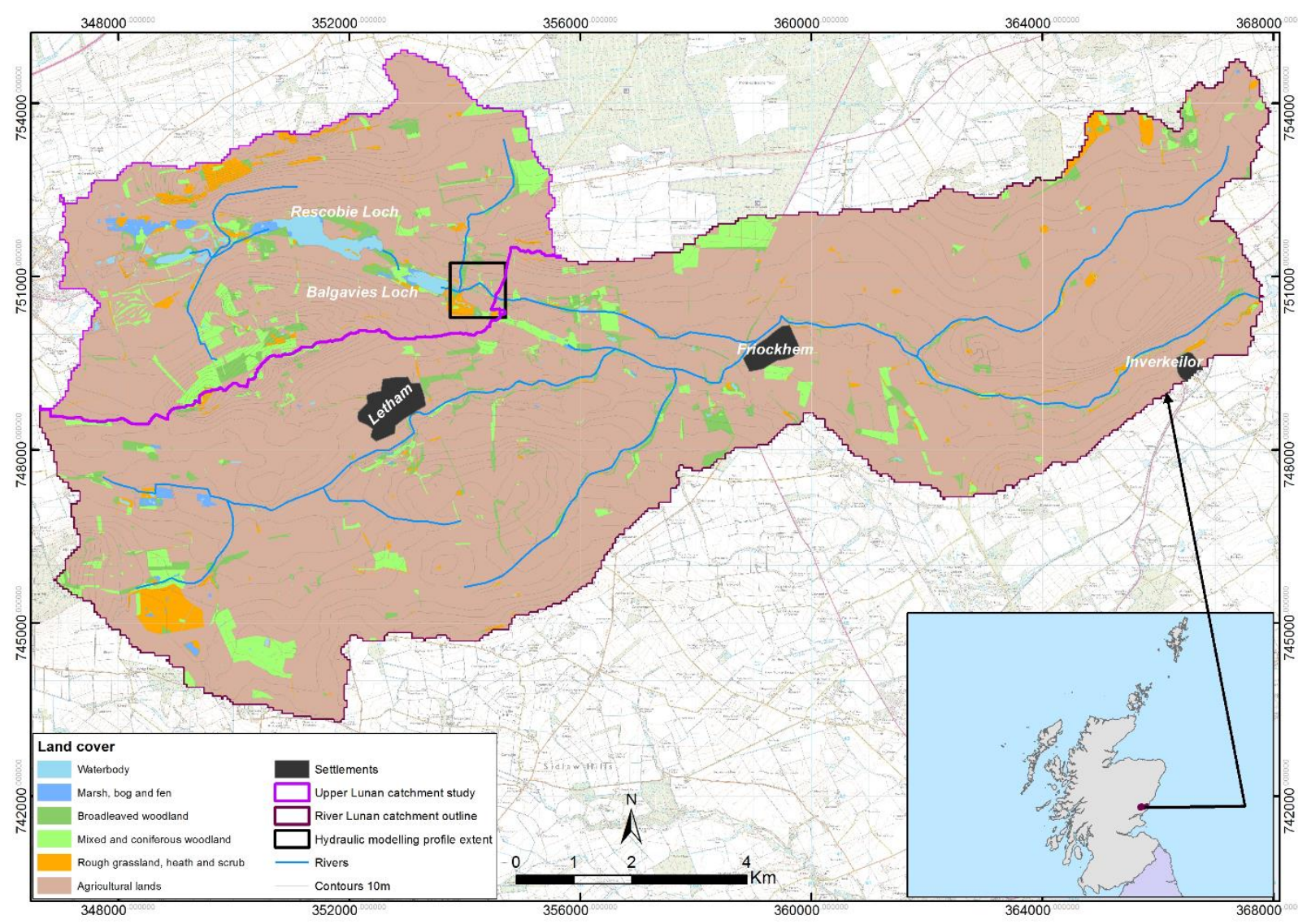

Figure 1. Overview of the Lunan Water catchment showing the main non-agricultural areas (MASTER MAP coverage), main settlements, the bounds of the upper Lunan Water catchment considered in this study, and the lake outlet zone where the hydraulic model was developed. (C) Crown copyright and database right (2019). All rights reserved. The James Hutton Institute, Ordnance Survey Licence Number 100019294 


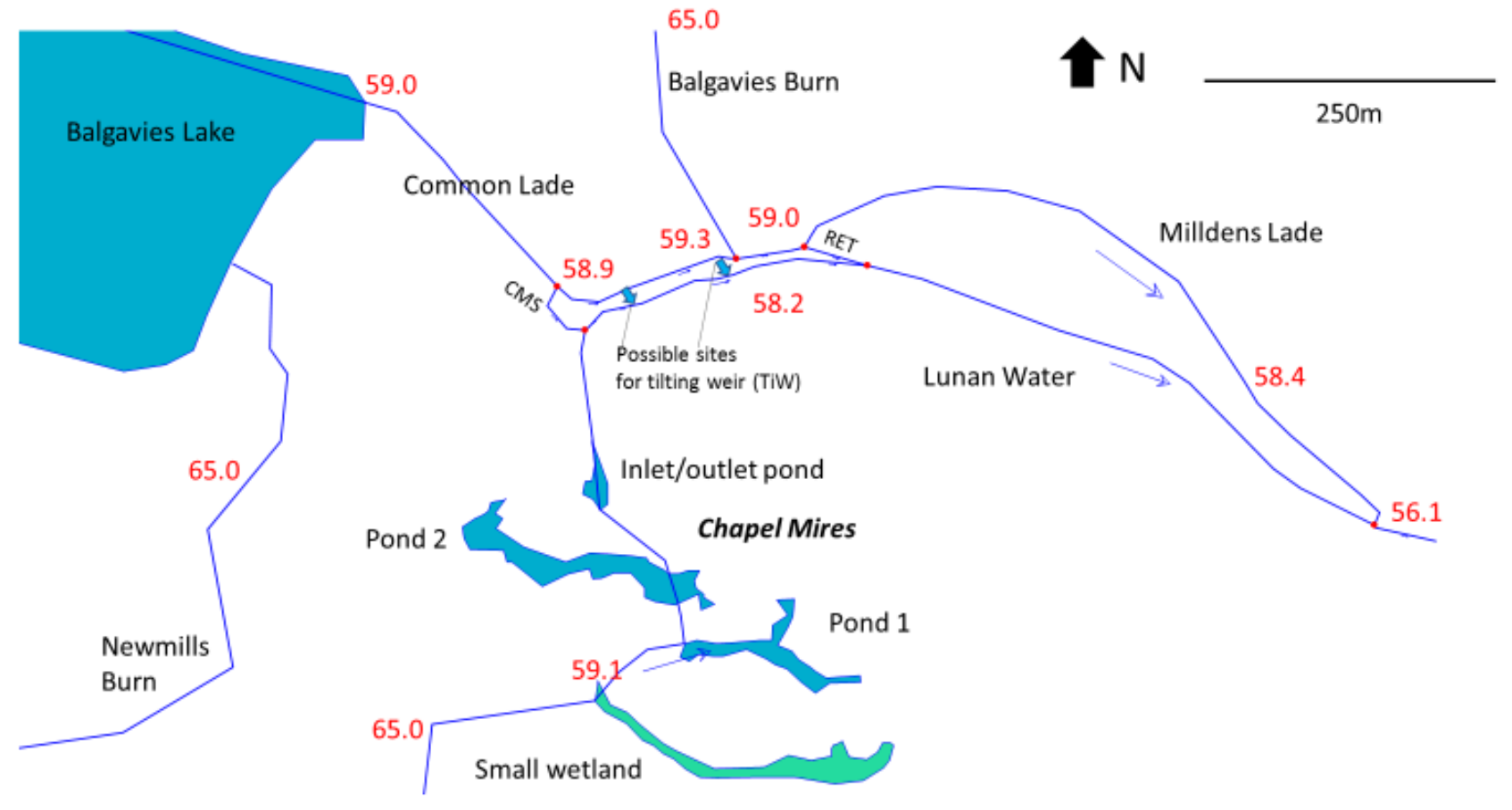

Figure 2. Detail of exit zone of Balgavies lake and Chapel Mires pertinent to steady state hydraulic model. Minimum Bed levels (in $\mathrm{m}$ above sea level) shown in red. CMS=Chapel Mires Spillway, RET=Return gate from Milldens lade to Lunan Water, TiW= possible sites for tilting weir. Note that the tailwater channel (Lunan Water) is not included in the steady state model used in this paper. More information on the section of the upper Lunan Water catchment downstream of Balgavies lake, including common lade, Milldens weir, Milldens lade, spillways and tailwaters, in the area downstream of the outlet to Balgavies lake, showing positions of proposed tilting weir and penning structure is given in supporting information 1 and 2 . 

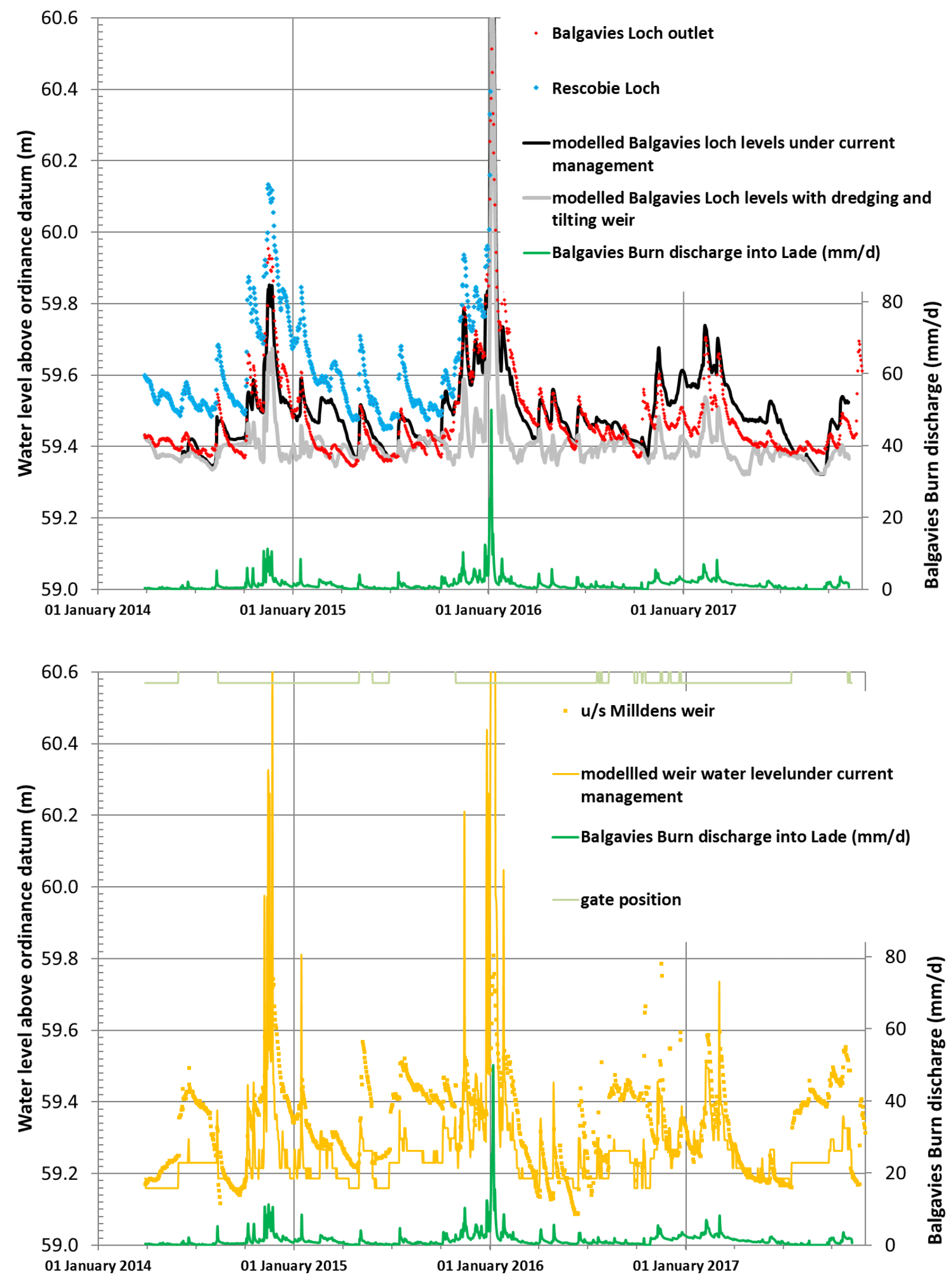

Figure 3. Top: Hourly water levels for Balgavies lake inlet (2014-2018) compared with modelled levels under current management and with tilting weir+dredging. Also shows water levels at Rescobie Lake and discharge from Balgavies Burn into common lade. Bottom: Hourly water levels for Milldens Weir, compared with modelled levels u/s of Milldens weir under current management and modelled water levels at Balgavies lake. Also shows whether gate is open (baseline) or closed (above baseline) and discharge from Balgavies Burn into common lade. 


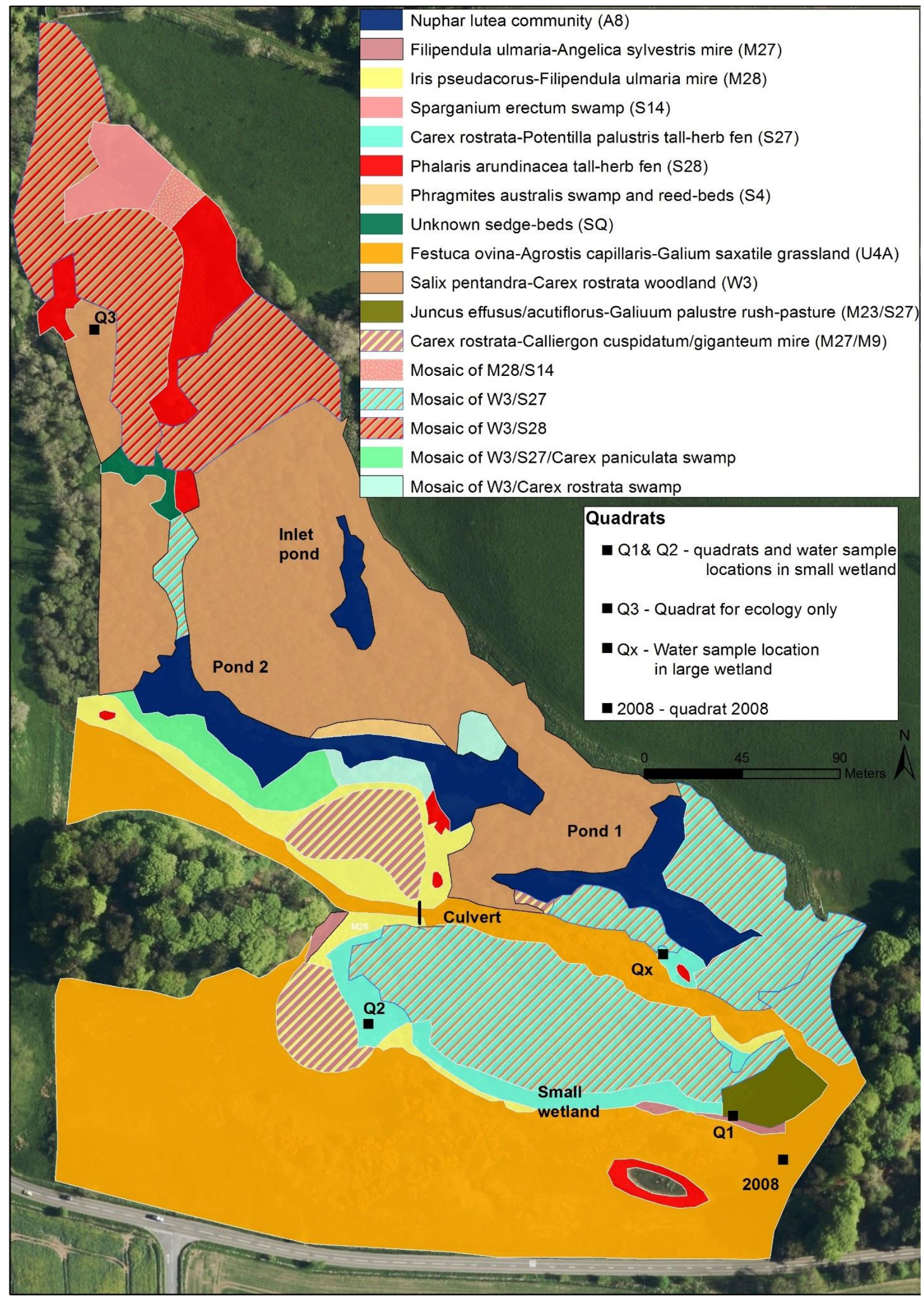

Figure 4. Rapid appraisal of UK National Vegetation Classification (Rodwell, 1995) of terrestrial wetland areas of Chapel Mires. Survey June 2017. Total area of Chapel Mires is $0.11 \mathrm{~km}^{2}$ Background (C) Copyright Getmapping plc 

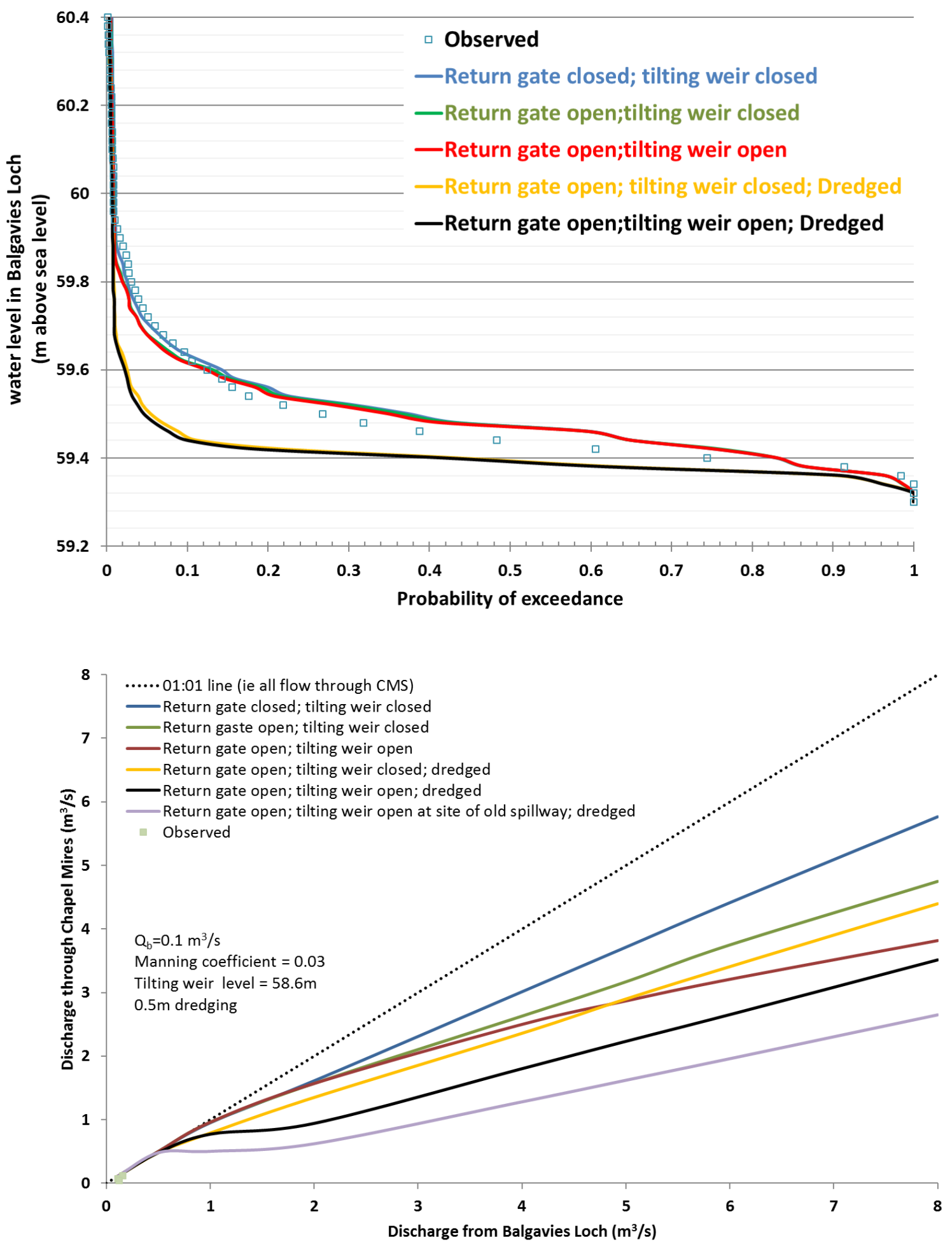

Figure 5. Top: Water level exceedance curves for Balgavies lake-observed compared with modelled values for March 2015-Nov 2017. Bottom: HECRAS simulations of the split of flow between Chapel Mires spillway and continuation down the common lade with different weir settings and dredging assumptions. 


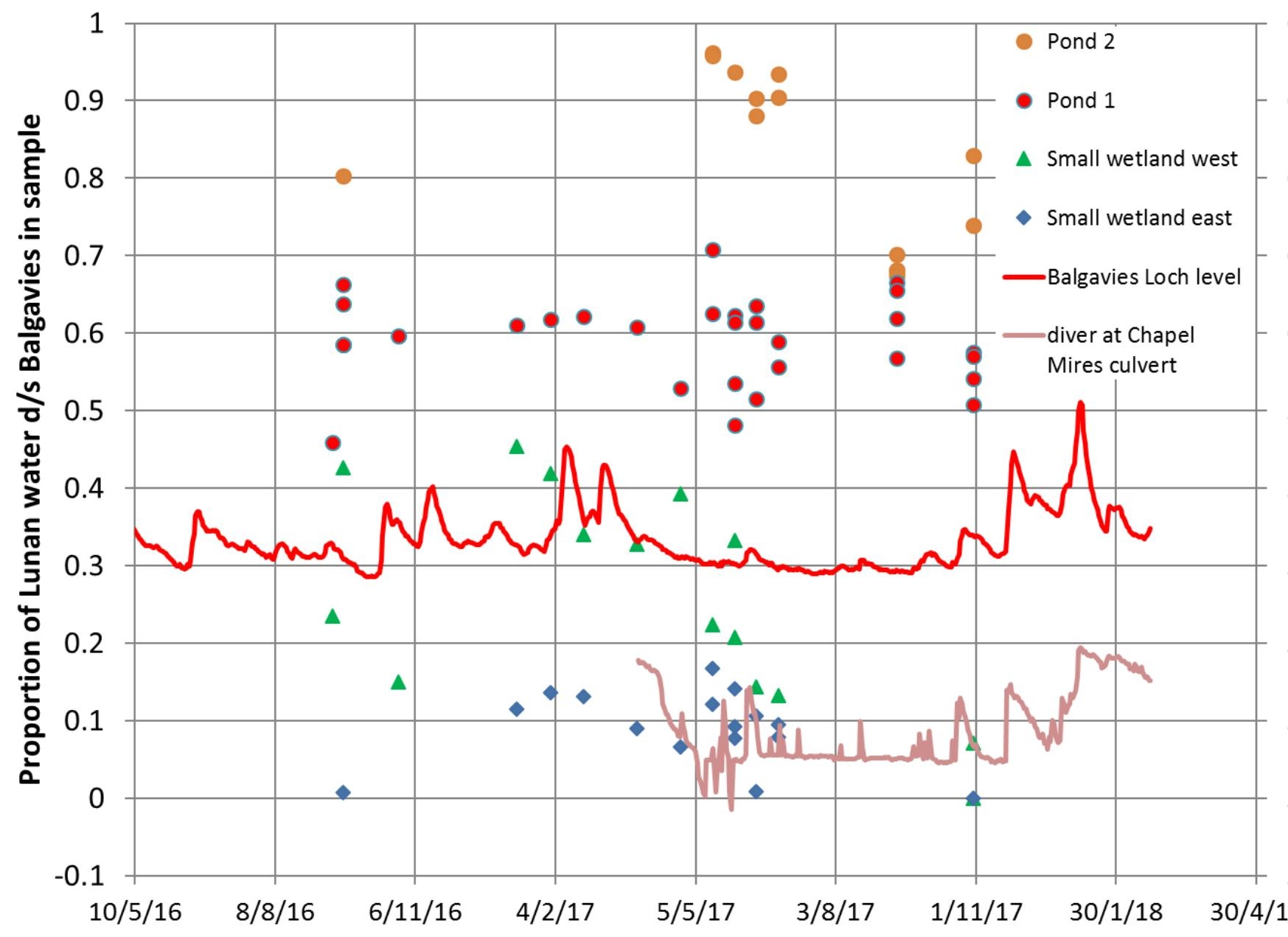

Figure 6. Estimation of the contribution of the Lunan waterd/s of Balgavies to the composition of samples in Chapel Mires wetland using EMMA. Also shown is the Balgavies lake water level, and the water level in a dipwell at the culvert between the small wetland and the ponds in Chapel Mires. 